\title{
JuVenile Crime and the Economic and Social Benefits of IMPLEMENTING EFFECTIVE Delinquency Prevention Programs: A Case Study of the District of Columbia
}

\section{By Jeffrey M. Poirier}

Abstract: This article includes a cost-benefit analysis of Functional Family Therapy (FFT), a program to reduce juvenile crime and delinquency. To illustrate that effective delinquency prevention programs and policy can benefit urban communities, this analysis uses the D.C. government as a case study to examine the expected outcomes of FFT. This analysis predicts that FFT will yield estimated total benefits of $\$ 8.3$ million and estimated total costs of $\$ 4.2$ million if the program were implemented over an eight-year period, resulting in a benefit-cost ratio of about 2. Policymakers in urban communities must recognize that the long-term savings of reduced juvenile crime, achieved by implementing evidencebased delinquency prevention and treatment services, exceed program costs. In response to juvenile crime, communities should develop comprehensive strategies of programs designed to reduce juvenile delinquency, guided by the large and growing body of research on effective prevention of delinquency, rather than turn to increased incarceration.

\section{INTRODUCTION}

Juvenile delinquency declined in many urban areas over the last decade, but remains a persistent problem that is preventable through effective treatment programs that efficiently use public resources. Juvenile crime affects most, if not all, communities including the District of Columbia (D.C. or District), which in the summer of 2006 declared an emergency due to

Jeffrey $M$. Poirier earned a B.A. in sociology at the University of Pennsylvania and has an M.A. in Education Policy Studies from The George Washington University, where he is enrolled in the Ph.D. program in public policy and administration. He is a Senior Research Analyst at the American Institutes for Research and has contributed to research on alternative education, education finance, international education, and juvenile justice. He co-authored a book chapter on the implications of failing to prevent emotional and behavioral disorders and articles on the needs of adjudicated girls and the prevalence of youth with disabilities in corrections. increased violence and an increase in juvenile involvement in crime (Williams and Ramsey 2006). This announcement occurred amid a media blitz that drew international attention and at times sensationalized the events as they unfolded: newspapers around the world covered the "Washington crime wave threatening tourism" (Canadian Press 2006) and particular crimes such as "the murder of a young British national who was slashed to death...in the upscale tourist district of Georgetown" (Agence France-Presse 2006). England's The Guardian reported on the "spate of violent robberies around Washington's most famous monuments" (Goldenberg 2006), Australia's Sunday Territorian drew attention to the "recent surge of violent attacks on residents and tourists" (2006), and The Irish Times noted that "violent crime is following the money into the city's swankier districts and to the historical sights favoured by tourists" (2006).

The author expresses deep gratitude to all reviewers and editors for their thoughtful input on the article. In particular, he would like to gratefully recognize his colleague and mentor, $D$. Mary Magee Quinn, for her steadfast guidance and support over the years. 
Avoiding unwanted publicity and its potential impact on trurism and local tax revenues is only one reason to support a strategic, community-based approach to decreasing crime. Government leaders have a responsibility to be proactive and establish or develop approaches to preventing juvenile crime rather than waiting for it to become problematic and turning to reactive approaches, such as increased secure confinement (incarceration) of youth who are delinquent. The potential for preventing crime should be a high priority on the agendas of policymakers as they decide how to effectively respond to juvenile delinquency and improve the safety of their communities.

In response to concern about juvenile crime, communities have relied on incarcerating youth who are delinquent. This punitive approach is not only costly but also ineffective; evidence from the 1990s shows that secure confinement neither reduces crime significantly nor reduces recidivism (Greenwald et al. 1998; Mendel 2004, 2001; Sexton and Alexander 2000). Furthermore, studies find that confining youth to correctional boot camps is not only ineffective but also inefficient: cost-benefit analyses show these programs result in monetary losses rather than cost savings (Aos, Phipps, Barnoski, and Lieb 2001).

Media coverage and public outrage about juvenile violence may contribute to policymakers' perceptions that the public largely endorses more punitive juvenile justice policy (Nagin et al. 2006,25). Although surveys find support for treating some juveniles who commit violent crimes the same as adults, public opinion is mixed. For example, in 2003, The Gallup Organization found that 59 percent of adults believed that society should treat juveniles between the ages of 14 and 17 who commit violent crimes the same as adults, but 32 percent reported that society should treat these youth more leniently in a juvenile court (U.S. Department of Justice BJS 2005, Table 2.48).

The challenge of effectively responding to public opinion exacerbates a political context in which fiscal concerns and constraints engender reluctance to fund delinquency prevention because of the long-term nature of the investment (Quinn and Poirier 2004). Legislators may not support delinquency prevention policy because of the difficulty in determining causal relationships between prevention efforts and outcomes and the desire, if not need, to show results to their constituents (NCPC 2003, 3). Also, government decision-makers may not fund more proactive juvenile justice activities because they do not consider the externalities of their decisions such as increased costs to other government agencies, other levels of government (e.g., state versus local), or the general public within their communities (NCPC 2003,3). For example, the American Youth Policy Forum asserts that localities do not sufficiently invest in communitybased juvenile corrections programs because existing financial arrangements incentivize communities to continue committing juvenile offenders to ineffective, but state-run, correctional facilities (Mendel 2001, 9). Furthermore, policymakers may be less knowledgeable of the burgeoning literature and research on delinquency prevention programs, which demonstrate that these activities can effectively reduce recidivism among participating youth and, as the Washington State Institute for Public Policy (WSIPP) ${ }^{1}$ and other cost-benefit analyses conclude, save public resources (Aos et al. 2001; Caldwell, Vitacco, and Rybroek 2006; Greenwood et al. 1998). To the extent this is true about policymakers, they may have a myopic perspective as they strategize local responses to crime and delinquency and prioritize spending of public resources.

To foster and advocate for a more informed approach to juvenile delinquency prevention policy, this article includes an ex ante ${ }^{2}$ cost-benefit analysis of one such program, Functional Family Therapy (FFT), that policymakers should consider as a means to reduce juvenile crime and delinquency. Research shows that FFT, which the Office of Juvenile Justice and Delinquency Prevention (OJJDP) of the U.S. Department of Justice identifies as a Blueprints Model Program, can reduce recidivism rates among participants (CSPV 2006). To illustrate that effective delinquency prevention programs and policy can benefit urban communities, this analysis uses the D.C. government as a case study to examine the expected outcomes of FFT. The findings provide estimates of economic benefits and costs of implementing FFT in D.C. if it implements this program at a site with a staff of eight therapists, the maximum number that can comprise a working group (DeMaranville 2003) over an eight-year period. ${ }^{4}$ Information on whether 
FFT can produce economic benefits for D.C. that are greater than its costs would further support the argument that delinquency prevention activities should be implemented (or expanded) in communities with a juvenile crime problem.

This analysis examines costs and benefits from the perspective of the D.C. government only; the counterfactual is the status quo. ${ }^{5}$ Because policymakers make decisions with the preferences of their constituency and limited budgets in mind, they may decide to allocate funds to more economically efficient programs if program costs do not outweigh their expected benefits. The benefits to other individuals (e.g., victims, juvenile offenders, and their families) and the broader community are important; a broader costbenefit analysis would include these. ${ }^{6}$ The current analysis excludes these other expected benefits to provide more conservative, less controversial findings based on D.C.'s direct expenditures.

This article begins by contextualizing delinquency prevention policy. It briefly discusses the history of juvenile justice in the U.S., expenditures on criminal justice, the extent of juvenile delinquency in the U.S. generally and D.C. particularly, and the latter's efforts to respond to the increase in juvenile crime in 2006. It then provides an overview of the underlying theory of delinquency prevention (i.e., protective and risk factors) followed by a description of FFT, including its purpose, program design, and anticipated outcomes for participating youth. Next, it identifies potential benefits and costs of implementing FFT and describes how the analysis quantifies program effects and the measurement of these effects. The analysis then monetizes predicted benefits and costs, uses these estimates to produce a ratio of total benefits and costs, and then discounts to present values. Although the analysis provides cautious estimates of benefits and costs, it also discusses how a sensitivity analysis and other considerations might alter the findings. The article concludes with a discussion and implications for policymakers in D.C. and other urban communities.

\section{A Brief Historical}

\section{Perspective of the}

\section{Juvenile Justice System}

Governmental approaches to juvenile justice in the U.S. have varied and evolved over the last 300 years. In fact, "the ways in which our society thinks about and responds to juvenile offenders tend to follow a cyclical pattern....there is a fairly continuous ebb and flow..., like a pendulum that swings between harshness and leniency" (Vito, Tewksbury, and Wilson 1998, 10). In the 1700 s, society tried older children accused of breaking the law but put children ages seven to 14 years old on trial only if the court determined they were able to distinguish between right and wrong; society viewed children below the age of seven as unable to act with criminal intent (Snyder and Sickmund 2006, 94; Vito et al., 9). Beginning in the $1800 \mathrm{~s}$, advocacy groups pushed for separate facilities for juvenile and adult offenders (Snyder and Sickmund). Although this led to the creation of privately owned facilities in many large cities, by the mid-1800s, states assumed responsibility for these facilities due to abuserelated concerns (Snyder and Sickmund). By 1899, Illinois became the first state to create a juvenile court, which it established on the philosophy that society should treat young offenders differently because of their need for compassionate care and opportunities for rehabilitation through treatment (Snyder and Sickmund, Vito et al.).

Within 25 years, most states created juvenile courts with jurisdiction of youth 17 and younger, ${ }^{7}$ but their approaches to juvenile justice have varied (Snyder and Sickmund 2006). These institutions had a greater focus on treatment in the 1960s and 1970s, but in the 1980s and 1990s, they emphasized more punitive approaches due to new state laws requiring mandatory sentences and (or) mandatory waiver of juvenile cases to criminal court (Snyder and Sickmund, Vito et al. 1998). The juvenile court philosophy of most states balances punishment with prevention and (or) treatment, but in some states, it emphasizes only one of these disparate approaches (Snyder and Sickmund). The following sections discuss the state of juvenile and criminal justice 
in the U.S., beginning with expenditures on related services, followed by the prevalence of juvenile delinquency as measured by atrests and delinquency cases in juvenile court.

\section{Criminal Justice Expenditures AND JUVENILE DelinQuenCy IN THE UNITED STATES}

The costs of the criminal justice system, including both juvenile-related and adult-related costs, ${ }^{8}$ continue to grow both in absolute dollars and on a per capita basis. Between 1982 and 2003, total government justice system expenditures increased fivefold from $\$ 35.8$ to $\$ 185.5$ billion, before adjustment for inflation (U.S. Department of Justice BJS 2005, Table 1.1.2003). Per capita expenditures also increased significantly during this period from about $\$ 158$ to $\$ 638$ (see Figure 1 ). These expenditures include the costs of corrections, the judicial and legal systems, and policy protection.

Arrest statistics collected from law enforcement agencies (LEAs) by the Federal Bureau of Investigation (FBI) and published in its Uniform Crime Reports (UCR) are a commonly used measure of crime (McCord, Widom and Crowell 2001, 26). ${ }^{9}$ Total juvenile arrests in the U.S. declined through 2004: Figures 2 and 3 display the recent declines in arrests for aggravated assault and robbery and property-related crimes. Table 1 shows that juvenile arrests in the U.S. decreased by about 20 percent between 1995 and 2004, with nearly similar percentage decreases in Violent Crime Index ${ }^{10}$ (VCI) and Property Crime Index ${ }^{11}$ (PCI) arrests (38.3 and 38.6 percent, respectively) and a smaller decrease in nonindex ${ }^{12}$ arrests (19.8 percent). However, 2005 data show that juvenile arrests for murder and robbery increased by 20 and 11 percent, respectively, between 2004 and 2005 (Butts and Snyder 2006, 4). Between January and June 2006, the most recent period for which data are reported, the number of violent crimes reported to LEAs increased by 3.7 percent (U.S. Department of Justice, FBI 2006). Although data suggest an increase in violent crime, predictions of increased violent crime may be overly reactive (Butts and Snyder 2006).

Juveniles accounted for a disproportionate decrease ( 29 percent) in the number of violent crime arrests between 1995 and 1999 (Butts 2000, 7), but the current juvenile share of crime is still significant. In 2004, juveniles accounted for one in 12 arrests for murder, one in seven arrests for aggravated assault, and one in four arrests for burglary and robbery (Snyder 2006, 4). ${ }^{13}$ Also in this year, 16 percent of violent crime arrests and 28 percent of property crime arrests involved juveniles (Snyder, 4).

Although the number of juvenile arrests is arguably an adequate indicator of juvenile crime, prior to interpretation, its limitations should be noted. Juvenile arrest statistics do not reflect the number of crimes or delinquent acts for a number of reasons. LEAs do not "clear" all crimes by an arrest(s): the annual arrest clearance rate, or proportion of cases closed due to an arrest or suspect identification, has dropped significantly in recent years (Christianson 2006). In 2005, LEAs cleared 45.5 percent of violent crimes and only 16.3 percent of property crimes (U.S. Department of Justice FBI 2006). Also, a number of offenses may precede one arrest, and the UCR classifies arrests based on the most serious offense charged per arrest (Snyder 2006, 2; McCord et al., 26-27).14

The number of delinquency cases in juvenile court is another indicator of juvenile delinquency, and expenditures on juvenile courts and juvenile detention facilities are other consequences of delinquency. Although primarily the role of LEAs, juvenile courts and prosecutors receive delinquency case refertals from schools, social service agencies, parents, and victims (Puzzanchera et al. 2004, 24). The first step, intake, begins with a decision to 1) formally process a juvenile's case by filing a petition to request a hearing, 2) informally process the case without a hearing, or 3) drop charges due to inadequate evidence (Mendel 2000, 55; Puzzanchera et al. 2004, 25) ${ }^{15}$ Juvenile courts also decide whether to detain youth in secure detention facilities. ${ }^{16}$ In some cases, such as serious offenses, the juvenile court may waive a juvenile case to adult criminal court. ${ }^{17}$ In the case of informal processing, juveniles and their guardians may agree to a behavioral contract (i.e., diversion plan) such as community service, counseling, probation supervision, or substance abuse treatment (Mendell, 55). ${ }^{18}$ Formal processing of a case 
in juvenile court incurs additional costs: it involves an adjudicatory hearing (i.e., trial) and depending on its outcome a disposition hearing (i.e., sentencing). ${ }^{19}$ Juvenile delinquency cases in the U.S. totaled about 1.6 million in 2002, which represents a 41 percent increase since 1985 (see Table 2) (Stahl 2006). Juvenile courts detained about 20 percent of these youth and found 38 percent delinquent.

\section{Preventing Juvenile}

\section{Delinquency}

A considerable body of empirical research suggests that juvenile delinquency is preventable. Advocates, researchers, and scholars within the juvenile justice and education fields view prevention as integral to addressing juvenile crime and reducing delinquency (Elliott 1998; Howell 2003; McCord, Widom, and Crowell 2001; Mendel 2000, 2001; Sprague and Walker 2000). They have also identified effective interventions to address antisocial behavior and help prevent initial or subsequent acts of juvenile delinquency. Prevention may focus on many different types of outcomes; can be part of programs associated with education, housing, law enforcement, or health and human services agencies; can target children of any age; and may focus on the communities of parents of youth (U.S. Department of Justice OJJDP n.d.).

Prevention progtams target factors that either place youth at risk of delinquent behavior or counteract these negative situational influences (National Center on Education, Disability and Juvenile Justice 2002). Research identifies circumstances that may affect the probability, severity, and extent of delinquent behavior. Risk factors increase the likelihood of delinquent and violent behavior, and exist in a number of areas of a youth's life:

individual (e.g., personal and social skills, substance abuse),

- family (e.g., family history of criminal behavior and conflict, poor family management skills, low parental involvement),

- school (e.g., academic failure, inadequate classroom management, truancy), peer (e.g., friends who engage in problem behavior), or community (e.g., access to drugs and firearms, poverty) (Howell 2003; Howell and Hawkins 1998; Christle et al. 2002; Kashani et al. 1999).

In contrast, strengths in the various domains of a youth's life such as good family communication and relationships, positive school attitudes, and low community crime are protective factors that can offset and build resistance to risk factors (Howell 2003). Whereas incarceration removes youth from their families and communities, complicating efforts to address the risks contributing to their delinquency (Sexton and Alexander), effective prevention ${ }^{20}$ directly addresses the multiple risk and protective factors of youth who are at risk or delinquent within their communities.

\section{Model Delinquency}

\section{Prevention Programs}

The Center for the Study and Prevention of Violence (CSPV) at the University of Colotado at Boulder works to identify effective violence prevention programs (CSPV 2004a). ${ }^{21}$ Of the 11 OJJDP Blueprints Model Programs programs, three address delinquency reduction; one of these is FFT (Sexton and Alexander 2000, 2002). The initiative's approach to selecting these programs is noteworthy because of the rigorous selection process and the requirement of a strong research design with evidence of program effectiveness. Each selected program must meet three core criteria used by the Blueprints Advisory Board ${ }^{22}$ :

1. Experimental designs with random assignment or quasi-experimental designs with carefully matched control groups.

2. Sustained effects for at least one year beyond treatment and no subsequent evidence the effects are lost.

3. Demonstrated teliability with at least one replication of the program at a different site and with positive outcomes (CSPV 2004b). 
The Advisory Board also "looks for evidence that change in the targeted risk or protective factor(s) mediates change in violent behavior" and program costs are "less or no greater than the program's expected benefits" (CSPV 2004b, $\$ 5$, I 2 and 3).

Two other Blueprints programs that target juvenile offenders include Multidimensional Treatment Foster Care (MTFC) and Multisystemic Therapy (MST) (Austin, Johnson, and Weitzer 2005; CSPV 2004a; Elliott 1998; Mendel 2001). This analysis models the potential cost-benefits of FFT for D.C., but policymakers should also consider these effective alternatives and others such as Aggression Replacement Therapy, Nurse-Family Partnership, and the Perry Preschool Program (Aos et al. 2001; Osher, Quinn, Poirier, Rutherford 2003). The next section describes the clinical model of FFT.

\section{Functional Family Therapy}

FFT is a family-focused prevention and intervention program targeting youth ages 11 to 18 who are at risk for, or are experiencing, delinquency (CSPV 2006). The program generally consists of eight to 12 hours of direct service (e.g., clinical sessions and telephone calls) over the course of three months, with up to 30 hours for the most severe cases (Sexton and Alexander 2002). The program can operate in many different settings, including the home, mental health agencies, juvenile courts, and schools and as of 2003 was implemented at over 100 sites (DeMaranville 2003). Communities implement FFT either as an intervention for youth who are involved in the juvenile justice system, to reduce the likelihood of future delinquency, or as a program to prevent delinquency among youth who are at risk (Sexton and Alexander 2000). The program may serve as a form of diversion or probation, as an alternative to secure confinement, or as part of an effort to facilitate a youth's reentry into a community following incarceration (Sexton and Alexander 2000).

FF'T follows a clinical model with specific phases that structure the intervention's delivery to reduce risk factors, enhance protective factors, and decrease the risk of ending the treatment early (Sexton and Alexander 2002). ${ }^{23}$ To accomplish its objectives, the program consists of three general phases: engagement and motivation (building the perception that positive outcomes can result from program participation), behavior change (developing and implementing plans intended to change problem behavior), and generalization (helping the family to maintain change and prevent recurrence of the behavior) (Sexton and Alexander, 2000, 2002). Each phase targets a number of risk and protective factors. For example, phase one builds credibility and decreases hopelessness, phase two targets parenting and communication skills, and the final phase focuses on relationships with school and the community (Sexton and Alexander 2000).

FFT requires clinical training and a client assessment, tracking, and monitoring system to support adequate adherence and competence in the program's model of service delivery (Sexton and Alexander 2002). FFT coordinators consult with the site weekly and provide on-site and other training activities during the initial year of implementation (Sexton and Alexander 2002). A site's clinical team can consist of up to eight therapists, including a lead therapist who receives specialized training to become the site supervisor. Therapists regularly staff cases of youth involved with the juvenile justice system, complete follow-up training, and receive regular consultation by telephone or in person. An Internet-based program supports the competence and skills of therapists by providing a system to manage client information, such as family and youth assessments, clinical decisions, and outcomes (Sexton and Alexander 2002).

Experimental clinical research, including randomized trials and nonrandomized comparison group studies, evidences that $\mathrm{FFT}$ "significantly reduces recidivism for a wide range of juvenile offense patterns" (Sexton and Alexander 2000, 5). Research dating back to 1973 shows that FFT can prevent initial delinquency and recidivism. Specifically, studies find that it reduces adolescent re-arrests by 20 to 60 percent (Sexton and Alexander 2000). For example, a randomized clinical trial in 1977 found that 20 percent of FFT participants recidivated compared to 46 percent of those assigned to a juvenile court program and 50 percent who received no treatment at all (Klein, Alexander and Parsons 1977, as cited in Sexton and Alexander 2000). The work of K. Hansson (1998), a study of FFT in Sweden, and J.F. Alexander and B.V. 
Parsons (1973) are other randomized clinical studies showing lower recidivism rates (both studies are cited in Sexton and Alexander 2000). ${ }^{24}$

Researchers recently examined the program's effectiveness at the largest FFT research and practice site in the U.S., the Family Project (Project) in Las Vegas. Over a two-year period, FFT staff contacted 231 families referred to the Project by probation officers, of which 80 percent completed FFT services (Sexton and Alexander 2000,6$)$. After the first year, the recidivism rate of those who completed FFT was just under 20 percent while that of the treatment group (i.e., those who received regular probation services) was 36 percent.

In its comprehensive review of FFT evaluations, WSIPP found an average effect size of approximately -0.25 for basic recidivism among program participants (Aos et al. 2001, 18). Given the rigor of WSIPP's meta-analysis of FFT evaluations, this cost-benefit analysis assumes that FFT can reduce future delinquency by 25 percent. This effect size is also at the lower end of predicted effects found in several of the aforementioned studies, making it a conservative estimate.

\section{A Policy Context: The District of Columbia}

Examining a community's approach to administering juvenile justice helps to illustrate how prevention of delinquency results in cost savings. This analysis uses D.C. as a case study. Public scrutiny and concern about D.C.'s juvenile justice system have led to its reform through new, progressive approaches to detention and treatment. As of the early 1990s, D.C. had one of the highest juvenile detention rates in the U.S., operating a system of three secure facilities to detain and (or) commit youth (Feldman, Males and Schiraldi 2001, 10). It eventually closed two of these facilities and replaced them with community-based detention alternatives due to highly publicized concerns about abuse, overcrowding, and safety (Feldman et al.). ${ }^{25}$ An evaluation in 1996 found that youth participating in these alternatives had lower re-arrest rates than youth detained in a secure setting (Feldman et al.).

The Department of Youth Rehabilitation Services (DYRS) is responsible for providing services to committed youth while they are at home, in group residential settings, or in a secure progtam. Currently, DYRS contracts a number of services for youth in non-secure settings, including home-based and individual counseling (DYRS n.d.a). ${ }^{26}$ DYRS detains youth at the Youth Services Center (YSC), which opened in 2004, and operates a separate facility to provide transition services for youth returning to the community. YSC can house and provide a number of services for up to 80 youth, including academic programs in collaboration with D.C.'s public school system, mental health services through the D.C. Department of Mental Health, and health and medical services (DYRS n.d.b). For transitioning youth, DYRS maintains the Trudie Wallace Pre-Release House. In this program youth reside, receive counseling services, and actively begin integrating into the community through opportunities such as jobs, job training programs, and community schools (DYRS n.d.b).

D.C.'s expenditures on criminal justice ${ }^{27}$ decreased over the 1992-2002 period. These expenditures decreased in both absolute dollars and as a percentage of total direct expenditures (from 12.3 to 7.9 percent, see Table 3). In per capita terms, though, D.C. spent more than four times the national average of criminal justice expenditures (U.S. Department of Justice BJS $1996,2005){ }^{28}$

The number of juvenile arrests in D.C. decreased in the late 1990s but fluctuated and increased in recent years. Juvenile atrests decreased from 3,916 in 1995 to 2,570 in 2002 (see Table 4) but increased in 2003, leading to an Urban Institute (UI) policy brief on juvenile crime in D.C. UI reported that high-profile juvenile crimes in D.C. during that year were not representative of a meaningful trend in youth violence in the community (Butts 2003). UI commented on the noteworthy decreases in juvenile violence and arrest rates in D.C. since 1995 as well as the significant decrease in delinquency cases referred to its juvenile court between 1990 and 2002 (Butts 2003). Although juvenile arrests did not reach the 1995 arrest level, the number of juvenile arrests increased to 3,093 in 2004 and jumped to 3,297 arrests in 2006 (sce Table 5; MPD 
2007a, 31). ${ }^{29}$ Using the most current data available, juvenile arrests between January 1 and March 31, 2007, were about 3.5 percent higher than during this same period in 2006, with juveniles accounting for about 7.2 percent of total artests in D.C. (MPD 2007b).

The juvenile crime problem in D.C. is further evident when comparing its recent increases to those in other urban communities using the juvenile arrest rate, the number of arrested youth (those under 18 years of age) per 100,000 residents ages 10 to 17 . In 2000 , D.C's juvenile arrest rate was 5,745 , or about one in 17 youth ages 10 to 17 , but this increased by about 8 percent to 6,272 in $2005 . .^{30}$ In contrast, many other urban areas ${ }^{31}$ experienced the opposite trend in their juvenile arrest rates between 2000 and 2004, the most current year of available data from the FBI's database. In fact, juvenile arrest rates decreased in a large majority of the urban communities in Table 6 (45 of 55) and these rates decreased by between 30 and 40 percent in 12 of the counties, including Bronx, Kings, and Queens counties in New York and Prince George's County, which lies in Maryland within Washington's metropolitan area.

In 2006, juveniles accounted for a small petcentage of total arrests in D.C. (6.1 percent) but a disproportionately larger percentage of atrests for more serious crimes such as aggravated assault (12.1 percent) and robbery (36.7 percent) (MPD 2007b). In comparison, a large proportion of the 51,000 adult arrests in 2006 were for non-serious offenses: almost two thirds were for non-violent crimes such as traffic violations $(10,980)$ and disorderly conduct $(6,545)$ (MPD 2007b). ${ }^{32}$ As of 2003, adults committed more deadly violent offenses than juveniles and accounted for a greater proportion of these offenses, making violent crime "largely an adult problem" in D.C. (Butts $2003,7)$. However, juveniles still accounted for nearly one in every five arrests for violent offenses in 2006 (MPD 2007b)..$^{33}$ The next section briefly describes the processing of delinquency cases by the D.C. Family Court and key related statistics.

After artest, a juvenile is either released with a warning or referred to juvenile court (Mendel 2000, 55). In 2005, D.C.'s Family Court processed 2,772 delinquency cases and detained about 7 percent of these youth (D.C. Superior Court 2006, 68). About 39 percent of these cases were for acts against persons, which mostly include assault (671 cases) and robbery (273 cases).

D.C. had a lower number of juvenile offenders in custody in 2003 than in 1975, but a larger number in 2001 (see Table 7). Moreover, the rate of placement per 100,000 juveniles increased in 2003 relative to the 1997 rate. The number of juvenile offenders in residential custody facilities in D.C. decreased between 1975 and 2003, when facilities housed 285 primarily male (90 percent) juvenile offenders; the total population of offenders was largely either Black, nonHispanic (81 percent) or Hispanic (12 percent) (U.S. Department of Justice BJS 2005).

In recent years D.C. responded to juvenile delinquency in various ways. For example, in 2003 D.C. policymakers considered harsher treatment of juveniles committing serious violent offenses by decreasing the age at which these youth could be tried as adults in criminal court (Butts 2003). In the following year, D.C. established a cabinet-level agency, the Department of Youth Rehabilitation Services (DYRS), ${ }^{34}$ with responsibility for juvenile detention, commitment, and aftercare (NCJJ 2006a).

Currently, D.C. policies provide services targeting youth at risk for delinquency through the Metropolitan Policy Department's (MPD's) Office of Youth Violence Prevention (OYVP) and DYRS. Presently, OYVP coordinates community efforts and supports programs and activities for youth who are at risk. This includes a basketball league that provides life skills training to participants, prevention/intervention workshops that address issues important to youth, and the Police Chief Youth Advisory Council that helps to advise the Chief of Police about youth-telated issues and perspectives and involves the Council's members in speaking to other youth on behalf of the MPD (MPD OYVP n.d.). The MPD's proposed operating budget for 2007 includes new youth violence prevention activities: conflict resolution $(\$ 371,103)$ and unspecified prevention and intervention initiatives $(\$ 293,715)$ (GDC 2006, C-21).

In contrast, DYRS is responsible for providing services to youth (e.g., those carrying out delinquent acts) who are committed to D.C.'s care. Current DYRS policy includes five types of community-based services: mentoring, substance abuse treatment and prevention, after-school enrichment (which provides general 
supervision and other services including tutoring and recreational activities), home-based counseling (including life and parenting skills training and group counseling), and individual counseling (DYRS n.d.a). In 2005, under the leadership of Director Vincent Schiraldi, DYRS collaborated with D.C.'s Department of Mental Health to implement Multisystemic Therapy and provide services to some justice-involved youth (Schiraldi 2006).

\section{The Enhanced Crime}

\section{Prevention and}

\section{Abatement Emergency}

\section{Amendment Act of 2006}

As mentioned, D.C.'s 2006 increase in crime and juvenile delinquency caught much attention, including that of the MPD and the Council of the District of Columbia (D.C. Council). Public concern undoubtedly percolated over coffee breaks in the hallways of Capitol Hill and university campuses, and amid office and neighborhood conversations throughout the city. On July 11, Chief of Police Ramsey (Chief) declared a crime emergency ${ }^{35}$ that required all MPD staff to increase their work weeks from five to six days effective July 17 (Williams and Ramsey 2006).

At the request of Mayor Anthony Williams, the D.C. Council convened from summer recess for an emergency session (Montgomety and Stewart 2006). It then declared a crime emergency through Resolution $16-779$ on July 19 and two days later enacted a crime prevention and abatement bill, D.C. Aat 16446 (Act), effective for 90 days (D.C. Council 2006a, 2006b). Among its provisions, the Act amended not only the Juvenile Curfem Act of 1995 to authorize Mayor Williams to modify curfew hours through executive order, but also D.C.'s municipal regulations to authorize D.C.'s Chief to use its closed circuit television (CCTV) system to prevent, detect, combat, and investigate crime (D.C. Council 2006a). ${ }^{36}$ The Act also increased accountability of the MPD ${ }^{37}$ and amended D.C. official code to require that the D.C. Family Court of the Superior
Court provide the Chief with case records of certain juveniles not detained by the Court. ${ }^{36}$

On October 19, 2006, the D.C. Council amended and extended the Act, adding the allocation of funding for the Mayor's Youth Development Strategy and public safety costs (D.C. Council 2006a). This included $\$ 5$ million for youth violence prevention efforts, $\$ 4.2$ million for MPD staff overtime, $\$ 1.7$ million for MPD CCTV operations, and $\$ 1$ million for extended hours and increased staffing at Department of Parks and Recreation centers. As reflected in the amendment, D.C. policymakers are willing to commit funding to delinquency prevention efforts.

\section{Benefits AND Costs}

This section discusses expected benefits and costs of implementing FFT in D.C. (see Table 8). The benefits and costs are borne by a large number of entities, including the D.C. government, victims of juvenile crime, families of victims and juvenile offenders, juvenile offenders, employers of victims, and the D.C. community. However, as explained previously, this analysis examines benefits and costs from the perspective of only the D.C. government because of the fiscal constraints it faces and its responsibility to use budgetary funds efficiently. This necessitates that policymakers prudently allocate resources.

As previously discussed, the assumed effect size of FFT is -0.25 , which is the anticipated reduction in recidivism due to FFT. Hence, a reduction in juvenile crime would benefit the D.C. government by reducing delinquency-related costs such as detention and commitment.. Specifically, the city would have fewer costs associated with serving juvenile offenders through the DYRS and incarcerating juvenile offenders in the adult correctional facility. This analysis assumes that the demand for policing will not change with the implementation of FFT at only one site; this effect is listed under "uncertain outcomes." If FFT were implemented on a larger scale in D.C., reductions in police-related costs in the long term might be feasible due to reductions in juvenile delinquency and the number of juveniles continuing to commit crimes when they become adults. This would be true if, for example, FFT decreased the likelihood of future crime 
emergencies requiring police overtime, or if FFT reduced the probability that participating youth will commit crime as adults.

Therapist compensation is the largest component of program costs. Implementation of FFT at one D.C. site would include a maximum of eight therapists. Although a community such as D.C. may hire an FFTcertified contractor to provide services, therapist salaries approximate the cost of this procurement. Although hiring a contractor to implement FFT would enable service delivery to begin in year one, and produce benefits in year two, this analysis assumes that D.C. incurs the costs to employ and train therapists. It also assumes that FFT services will occur at the juvenile court, an existing community clinic, or at the homes of youth, and does not include the cost of space for service delivery.

The D.C. government will incur a number of direct implementation costs associated with site certification and staff training during phases one and two of the program (Kopp 2004, Sexton and Alexander 2002). Phase one, occurring in year one, consists of clinical training to create therapist adherence and competence in the model. These costs include fees and travel expenses for an FFT consultant to provide a two-day clinical training to the therapists at the D.C. site providing FFT services. The group of therapists also participate in group telephone consultation for one hour each week during the course of year one and the consultant conducts two follow-up visits to the site. Also during phase one, the eight therapists participate in a two-day clinical team training at either Indiana University or the University of Utah, where FFT coordinators are located. The D.C. FFT supervisor (the lead therapist) participates in an externship and attends three additional two-day training sessions at the Indiana University Center for Adolescent and Family Studies. Activities involving travel will require resources for airfare, lodging, per diem, ${ }^{39}$ and local transportation.

Phases two and three, occurring in years two and three, consist of additional activities to enable the D.C. site to take over clinical consultation of the eight therapists and to provide continuing education in support of model fidelity (Sexton and Alexander 2002). During phase two, the D.C. FFT lead therapist participates in two, two-day training sessions at Indiana University and monthly phone meetings with FFT consultants. In addition, an FFT consultant(s) conducts a one-day visit with the D.C. FFT supervisor at the D.C. site and reviews the clinical services database for issues of model adherence, outcome, and service delivery trends. During phase three, the FFT consultant(s) conducts a one-day follow-up training with the FFT lead therapist and again reviews database for the aforementioned issues. In the sections the follow, the analysis quantifies the predicted benefits and costs by estimating their monetary value.

\section{Estimated Benefits of}

\section{Functional Family Therapy}

FFT program coordinators expect each therapist to handle 12 to 15 cases at any time and complete each case within three months, totaling 48 to 60 cases annually (DeMaranville 2003). This analysis assumes that the eight therapists will serve 432 youth annually (54 per therapist) and FFT will prevent 25 percent, or 108 , of these youth from committing delinquent offenses beginning in year three. It assumes that without the intervention, recidivism would occur within one year of program participation and that these offenses would result in arrests and prosecution. Therapists would begin serving cases in phase two and are predicted to prevent 756 juvenile offenses (108 youth multiplied by seven years) and telated arrests from years three to nine.

This analysis quantifies benefits using this estimate of prevented juvenile offenses and D.C.'s DYRS operating budget ${ }^{40}$, as well as 2006 juvenile arrest and commitment data. The benefits of implementing FFT are the accrued savings due to reduced costs associated with juvenile crime. Estimated savings are complex and uncertain: although intuitively one can assume that juvenile cases involving minor, non-violent offenses or youth not previously involved in the juvenile justice system require fewer resources such as court costs and length of confinement, available information to make these estimates is too limited. Therefore, this analysis assumes that each prevented juvenile offense will decrease costs for the D.C. government in an equal proportion. About 5 percent of DYRS's operating budget is allocated to energy and fixed costs (e.g., building and land rentals), which the analysis assumes will not decrease with prevented juvenile offenses.

Table 9 presents FFT-related savings with and without energy and fixed costs. Estimated savings over the implementation period total $\$ 8,771,154$, with benefits beginning in year three and, for the purpose of this analysis, ending in year nine. Because the analysis assumes that benefits occur in the year following FFT 
treatment delivery to a cohort of participants, estimated benefits continue into year nine even though the analysis assumes the program ends in year eight.

For the 2007 fiscal year, the D.C. government budgeted $\$ 25,793,692$ for detained services, which includes supports to link youth to their community, security and food services, and oversight to youth prior to community placement (GDC 2006, E-62). The DYRS Research and Evaluation Unit reports that 1,293 of the youth arrested in 2006 were placed in secure detention (Balis 2007). In total, about 39 . percent of arrested youth were admitted to secure detention (number of detained youth divided by the number of juvenile arrests as reported in Table 5). Using the projected budget and data on secure detention admissions, the estimated average cost of providing detained services to each youth is $\$ 19,949$ ( $\$ 25,793,692$ divided by 1,293 detained youth). Assuming that FFT prevents 108 juvenile crimes and arrests annually, of which 39 percent (or 42 cases) result in secure detention, the program would produce an estimated annual savings of $\$ 837,858$ ( $\$ 19,949$ multiplied by 42 ) in reduced costs for detained services.

For the same fiscal year, D.C. budgeted $\$ 24,079,571$ for committed youth services, which include community, food, and security-telated services (GDC 2006, E-161). The District committed 262 additional juveniles to DYRS in 2006, with 770 total commitments in this year (Balis 2007). On average, each committed juvenile resulted in an estimated cost of $\$ 31,272(\$ 24,079,571$ divided by 770$)$ and about one in 13 (7.9 percent of) juvenile arrests resulted in commitment to DYRS (262 commitments divided by 3,297 juvenile arrests). Based on this assumption, FFT would reduce the number of annual commitments to DYRS by nine (108 prevented juvenile crimes multiplied by 7.9 percent). ${ }^{41}$ This would result in a savings of about $\$ 281,448$ annually $(\$ 31,272$ multiplied by nine).

In addition, D.C. allocated $\$ 5,163,346$ for medical services for detained and committed youth in its 2007 budget (GDC 2006, E-162). Based on the total number of detained and committed youth in 2006, these costs average about $\$ 2,502$ per juvenile $(\$ 5,163,346$ divided by 2,063$)$. If FFT prevents nine juvenile offenses that would otherwise result in commitment to DYRS and 42 offenses that would result in secure detention, then the program would save $\$ 127,602$ in medical services costs annually $(\$ 2,502$ multiplied by 51$)^{42}$
Another component of savings due to prevented juvenile offenses is associated with the costs of D.C.'s Department of Corrections. In 2003, 1.2 percent of inmates were under eighteen at the time of booking and in 2006 juveniles account for 15 of the average daily population (ADP) of 3,543 inmates (D.C. Department of Corrections 2003, 2007)..$^{43}$ D.C.'s 2007 proposed operating budget for corrections includes $\$ 39,115,841$ for inmate services ${ }^{44}$ and $\$ 72,261,097$ for inmate custody ${ }^{45}$ (GDC 2006, C 48 to C-50). On average, daily services and custody costs come to approximately $\$ 86$ per inmate (Department of Corrections 2007). ${ }^{46}$ Although one can argue that delinquency prevention would reduce the number of youth (and young adults) committing offenses that would lead to their involvement in the correctional system, data are too limited to make a confident estimate of these reduced costs. Therefore, this analysis provides this information for consideration but excludes it from the estimated cost savings.

\section{Estimated Costs of}

\section{Functional Family Therapy}

As discussed in the section on predicted program costs, implementation of FFT would incur direct costs for consultants, travel, communication, and therapist compensation. FFT program coordinators provide consultant and estimated travel costs including airfare, lodging, meals, local transportation, and airport parking (Kopp 2004). Table 9 displays these costs by phase for eight therapists. Estimated consultant and travel costs total $\$ 92,413,{ }^{47}$ The long-distance communication costs, estimated at $\$ 0.05$ per minute (Verizon 2007$)^{48}$, total $\$ 444$ (see Table 10 ). ${ }^{49}$

To approximate therapist salaries, this analysis uses D.C. wage data from the Bureau of Labor Statistics (BLS), which collects data from employers and reports estimated wages by industry and occupation. BLS reports that child, family, and school social workers in D.C. had a median hourly wage of $\$ 18.38$ and a mean hourly wage of $\$ 19.14$ in 2005 (U.S. Department of Labor 2005). To attract a highly qualified staff, this analysis assumes that D.C. compensates therapists 20 percent above the median hourly wage, or $\$ 22.06$ $\left(\$ 45,885\right.$ annually) ${ }^{50}$ and the lead therapist 40 percent above the median hourly wnge, of $\$ 25.73$ ( $\$ 53,518$ annually). ${ }^{51}$ It escalates salarics at a tate of 4 percent 
annually ${ }^{52}$ and includes estimated fringe benefits ${ }^{5.3}$ (see Table 11). Therapist salaries and fringe benefits in the first year total $\$ 447,785$ ( $\$ 54,833$ for each of seven therapists plus $\$ 63,954$ for the lead therapist). Table 12 presents total costs by program year.

\section{Cost-Benefit Analysis}

Table 13 presents the estimated and quantified annual costs and benefits of implementing FFT in the District. Over the nine-year period, estimated total benefits are about $\$ 8.3$ million, whereas total costs are just over $\$ 4.2$ million This yields an estimated net benefit of $\$ 4$ million, and a cost-benefit ratio of about 2.0 . For each dollar the D.C. government invests in FFT, it will save an estimated $\$ 1.97$, on average.

Table 14 presents discounted benefits and costs because they vary across time periods, with costs but no benefits in years one and two and benefits but no costs in year nine. This analysis uses the recommended real discount rate of 7 percent that the Executive Office of the President, Office of Management and Budget uses to convert monetary calculations to present values. The present value of benefits is nearly $\$ 6$ million and the present value of costs is $\$ 3.3$ million; the discounted net present value is about $\$ 2.6$ million. This yields a present value cost-benefit ratio of about 1.8. Figure 4 illustrates the annual discounted benefits and costs of FFT.

\section{SENSITIVITy ANALYSIS AND}

\section{LIMITATIONS}

This analysis does not include certain expected benefits and costs because it considers only direct savings for the D.C. government. A broader analysis would include groups such as victims, families of victims and offenders, and the D.C. community. One can confidently anticipate that in a more inclusive approach the social benefits would be significantly greater than the sociat costs of implementing FFT at one site in the District. Also, because FFT is family-focused, participation may yield additional benefits by decreasing the likelihood of sibling delinquency.

Overall, this analysis uses conservative estimated magnitudes and assumptions to produce a lower-thanexpected cost-benefit ratio. Because the estimates are cautious but the net present value of FFT is still positive by a relatively large margin, one can anticipate that sensitivity analysis would increase the net present value of FFT. Further, this analysis applied a low estimated effect size to predict the decrease in juvenile offenses. If the analysis applied a higher effect size found in some evaluations of FFT, then the benefits would increase. The expense of prevented police overtime, which the D.C. Council (2006a) allocated $\$ 4.2$ million for during the 2006 crime emergency, is a savings that might be included when re-examining the findings of this analysis

Predicted benefits are critical magnitudes and might vary. To account for this variation, a sensitivity analysis might adjust the per juvenile costs for detained and (or) committed youth services to account for uncertainty about how the assumed average savings compares to the actual prevented costs of program participants. More specifically, some juvenile delinquent acts might incur greater costs due to the nature or severity of the case. The analysis assumes that the program would randomly select juveniles to control for this variation in type of crime. However, the program might prevent future juvenile crime that would be either more or less than the average cost. To the extent this occurs, the analysis may over- or underestimate the economic benefits.

The analysis also uses cautious estimates of predicted costs. To bias the results toward a more conservative estimate of benefits, the analysis estimates therapist salaries at 4 percent, but not the prevented per juvenile costs that will also very likely increase annually. These salaries are estimated at 20 percent above the mean therapist salary for D.C.; the lead therapist salary 40 percent above the mean. Estimating therapist salaries at a lower or greater percentage above the mean salary (e.g., 30 percent) is one approach to evaluating the sensitivity of the findings. A sensitivity analysis might also adjust other program costs slightly and should include therapist re-training costs to account for staff attrition over the eight-year period. Program designers indicate that therapists should complete 48 to 60 cases every three months; this analysis uses the mean (54) to estimate benefits. It might be valuable to use the ends of the distribution (48 and 60) of the 
expected caseload to examine how estimated benefits change.

Decreased tax revenues, a secondary cost, are another potential crime-related outcome that the modeled cost-benefits might include to examine variation in the results. The District's economy thrives on tourism and its related industries (e.g., entertainment, food and beverage, lodging) and highly publicized crime may impact them. During 2005 about 14.1 million domestic and 1.3 million international visitors came to D.C. and spent more than $\$ 5$ billion, sustaining more than 59,000 jobs (full-time equivalent) and almost $\$ 543$ million in local tax revenue for the city government (WCTC 2006). Although the effects of increased juvenile crime, or increased crime committed by juveniles who become adult criminals, on the tourism industry is uncertain, one can reasonably assume that some impact is likely.

Even a negligible effect on the behavior of D.C. toutists and area residents bolsters the findings of this analysis. If personal safety concerns cause one in 1,000 of the leisure visitors projected to visit D.C. in 2007 to travel elsewhere, city businesses will lose revenues totaling about $\$ 6.9$ million and the city government will lose hotel and sales tax revenues of about $\$ 170,000 .^{54}$ Additionally, the crime wave could decrease the number of business visitors if, for example, conventions and group meetings (which accounted for 35 percent of the seven million business visitors in 2005) decide to hold future meetings in other "safer" cities (WCTC). Potential job losses, which could increase residents' dependence on city social services, and other effects such as decreased local tax revenue due to lower corporate and personal income are other potential consequences of increased crime.

Augmented perceptions of a climate of crime in D.C., no matter how overstated, might also decrease the presence of Washington's suburban "Beltway" residents, who may opt instead to purchase goods and services in their local communities - not to mention D.C. residents who avoid the city's streets (and businesses) at night. In fact, The Gallup Organization's public opinion surveys in 2003 and 2005 found that nearly one in two respondents avoid certain places or neighborhoods they would otherwise visit due to concern about crime (U.S. Department of Justice BJS 2005, Tables 2.40 and 2.40.2005). ${ }^{55}$
Finally, it is important to note several limitations of using juvenile arrest statistics as an indicator of juvenile crime. These data may understate juvenile delinquency because juvenile crime does not always result in an arrest and because arrest reports count an individual's most serious charge only (Mendel 2000, MPD 2007b). In contrast, arrest statistics may overstate juvenile crime because one offense may result in arrests of multiple juveniles. Moreover, the handing of juvenile arrests raises questions about whether arrested youth are, in fact, delinquent: in some cases police release arrested youth with a warning and in other instances they are referred to juvenile court, where the cases may be dismissed (Mendel 2000).

\section{Discussion AND IMPLICATIONS}

This ex ante cost-benefit analysis examines the economic effects of implementing FFT in the District. FFT would reduce recidivism among program participants by about 25 percent or 54 juvenile crimes per year. As a result, the D.C. government will produce benefits of about $\$ 1.2$ million annually beginning in year three. Total annual program. costs range from $\$ 492,172$ in year one to $\$ 594,939$ in year eight. FFT will yield estimated total benefits of about $\$ 8.2$ million over the nine-year period; estimated costs total approximately $\$ 4.2$ million resulting in a cost-benefit ratio of about 2.0; using present values this ratio is 1.8 .

These findings do not include another benefit of preventing crime and delinquency: avoiding or reducing negative media attention and its potential impact on D.C.'s tourism industry. In 2006 , the negative publicity likely caught the attention of potential D.C. visitors, especially after four teenagers and a twenty-two-yearold participated in tourist-targeted crimes on the National Mall. The victims included a Missouri family of four and two females from Texas, one of whom was sexually assaulted (Allison Klein 2006a).

Cost-benefit analyses such as this may help to persuade policymakers to fund effective delinquency prevention programs. Based on the conservative assumptions and inputs used in this analysis, implementation of FFT would provide direct economic and social benefits for the District. This 
rational perspective is but one approach to considering prevention policy: it is also a morally appropriate and responsible investment because it supports the community's youth who are most at risk for delinquency. Black youth make up a large majority of juveniles who are delinquent in the District. NonHispanic Black residents under 18 years of age accounted for 72 percent of the city's youth population in 2004 but nearly 100 percent of the city's children receiving TANF and food stamps in 2005 (D.C. KIDS COUNT Collaborative, 2005).

Several other relevant considerations are important to raise because of their potential to increase government savings and program benefits in the long term, but are not within the scope of this article to discuss further. First, although data on recidivism (reoffending) rates is limited due to variability in its measurement, three state-level studies using re-arrest statistics found that 55 percent of juveniles recidivated over a twelve-month period (Snyder and Sickmund 2006, 234). Second, some juveniles who become early and chronic offenders are more likely to continue on pathways to adult criminality (Howell 2003, 56). Hence, interventions reaching these juveniles may be particularly beneficial: effective prevention efforts today may mitigate future delinquent behavior and prevent some youth from transitioning to adult criminality.

Policymakers must recognize that the long-term savings of reduced juvenile crime, achieved by implementing evidence-based delinquency prevention and treatment services, exceed program costs. They also should actively communicate the expected benefits of prevention programs to their constituents to enhance public support. Historically "the funding of prevention programs has been a battle between social scientists, who champion efforts to fund programs that are more effective for children and adolescents, and policymakers who have an obligation to those they are elected to represent to be circumspect and efficient with public funds" (Quinn and Poirier 2004, 88). District policymakers and those in other communities need to address any public resistance or uncertainty by educating the public and collaborating with advocates of delinquency prevention efforts to emphasize the benefits of providing non-traditional supports or services to youth who are delinquent.
Public support for prevention may be stronger than expected. Recent research finds strong public support for policies intended to reduce juvenile crime and a greater willingness to pay (WTP) for juvenile rehabilitation and prevention programs in comparison to incarceration. For example, a 2005 contingent valuation (CV) study ${ }^{56}$ measuring participants' WTP for rehabilitation and prevention programs versus incarceration found that WTP was higher for the former (Nagin et al. 2006). ${ }^{57}$ Specifically, Nagin and his colleagues found that 60 percent of respondents were willing to pay at least $\$ 100$ in additional taxes to add a rehabilitation program, which would decrease juvenile crime by 30 percent, to the typical term of juvenile incarceration for serious crimes (one year); another 10 percent were willing to pay at least $\$ 50$ dollars and 27.8 percent were unwilling to pay for the program (Nagin et al. 15). In contrast, a greater proportion of respondents ( 40.8 percent, significant at $\mathrm{p}<.01)$ were not willing to pay for an additional year of incarceration, which would have the same effect on juvenile crime; 50 percent were willing to pay at least $\$ 100$ for the additional year of incarceration.

Delinquency prevention is not a panacea, but D.C. and other urban areas must recognize its potential benefits and cost efficiency. This analysis shows that FFT is an economically efficient use of the D.C. government's resources. This key finding provides strong evidence that D.C. should fund and implement at least one FFT site that is staffed with eight therapists for at least an eight-year period.

In response to juvenile crime, communities should develop comprehensive strategies of programs designed to reduce juvenile delinquency (Butts 2003) rather than turn to increased incarceration and other punitive and often ineffective approaches. Some communities have already implemented prevention programs in response to juvenile crime. Those that have not should turn to the large and growing body of research on effective delinquency prevention programs, including the Center for the Study and Prevention of Violence as well as the Washington State Institute for Public Policy, to guide the development of their local delinquency prevention policy. As two prominent juvenile justice researchers recommend, prevention efforts should target youth between the ages of 15 and 24 who are at risk, live in poor neighborhoods, and are separated from school and 
family (Butts and Snyder 2006). Cost-benefit analyses such as this one can help to develop the necessary political will, which is one of the greatest challenges to prevention policy, by "establish[ing] the connections between preventive investments, people's wallets, and personal safety" (Osher, Quinn, Poirier, and Rutherford 2003, 112).

\section{Notes}

${ }^{1}$ The Washington legislature commissions WSIPP to conduct research and analyze various public policies on behalf of the state's legislature and governor. WSIPP conducted a cost-benefit analysis of numerous programs intended to reduce criminal activity (both adult and juvenile). FFT was one program examined by WSIPP.

${ }^{2}$ An ex ante (forwatd-looking) analysis occurs prior to program implementation and extrapolates anticipated outcomes.

${ }^{3}$ The Center for the Study and Prevention of Violence (CSPV) at the University of Colorado at Boulder commissioned by the Centers for Disease Control and Prevention, the Colorado Division of Criminal Justice, and the Pennsylvania Commission on Crime and Delinquency in 1996, and subsequently by OJJDP identifies Blueprints for Violence Prevention, or "Blueprints" programs that effectively reduce violence (CSPV 2004a). Of the 11 Blueprints programs, three are designed to reduce delinquency; one of these is FFT. See the section on model delinquency prevention programs for more information about the Blueprints programs.

${ }^{4}$ The period of analysis is eight years to provide evidence of how benefits compare to costs over two, four-year mayoral terms.

${ }^{5}$ In cost-benefit analysis, the "counterfactual" is the assumed situation if a program is not implemented. These analyses may assume that a client will do nothing as the alternative to implementing the program analyzed.

'A large body of research examines these other costs, although they are not always disaggregated by adult and juvenile crime costs (for example, see Aos et al. 2002; Cohen 2000, 1998; Miller, Fisher, and Cohen 2001).
7 This article uses "youth" interchangeably with "juvenile," although some juvenile justice researchers use the former label for those who are 15 to 24 (Butts and Snyder 2006).

8 The Bureau of Justice Statistics reports aggregate expenditures on corrections: these data are not specific to juvenile-related costs.

${ }^{9}$ Other measures of crime include victim reports of crimes from the National Crime Victimization Survey (NCVS) and self-report surveys. The NCVS, which surveys about 43,000 households each year, collects data on individuals' experience with crime but has several limitations including overestimated crime rates because of participants' tendency to include crimes that occurred in previous periods of time not included in the survey (McCord et al., 29-30). Surveys collecting self-reports of delinquent behavior may be administered in schools, which biases the results by excluding youth who ate absent, dropped out, or ate homeless - and delinquency rates are higher among youth who have dropped out of school (McCord et al., 30). In addition, some research shows that selfreport data may be less valid in the case of females and black or nonwhite youth (McCord et al., 31).

${ }^{10}$ The VCI includes aggravated assault, forcible rape, murder and non-negligent homicide, and robbery (Puzzanchera et al. 2006).

11 The PCI includes arson, burglary, larceny-theft, and motor vehicle theft (Puzzanchera et al. 2006).

${ }^{12}$ Nonindex crimes include 21 offenses not included in the VCI or PCI such as disorderly conduct and vandalism (Puzzanchera et al. 2006).

${ }^{13}$ Statutes setting age limits for "juvenile" status vary by state and determine whether juvenile or criminal courts have jurisdiction over a youth charged with a law violation (Snyder and Sickmund 2006).

${ }^{14}$ Other limitations of arrest statistics as an indicator of crime and delinquency include: non-reporting of some crimes, one crime leading to arrests of several individuals (and juveniles are more likely than adults to commit crime as a group), and arrests of individuals who are not necessarily guilty of the crime(s) leading to their arrest (McCord et al., 26-27; Snyder 2006). 
${ }^{15}$ In some jurisdictions the juvenile probation department assumes authority for the intake process, in others prosecutors are responsible (Mendel 2000, $55)$,

${ }^{16}$ Juvenile courts may detain youth to protect the community, to ensure that a youth appears at court hearings, or to evaluate the youth (Mendel; Puzzanchera).

${ }^{17}$ To waive a case, prosecutors may either file a case in adult criminal court (according to state statute and based on the offense) or schedule a hearing in juvenile court to request judicial waiver of the case to criminal court (Mendel; Puzzanchera).

${ }^{18}$ If youth fulfill the terms of the contract prosecutors may drop charges, but if youth do not, then the case may be processed formally (Mendell).

${ }^{19}$ Prosecutors may request a heating during which the court reviews evidence and either adjudicates the youth as delinquent (i.e., found guilty) or dismisses the case (Mendel; Puzzanchera). If found delinquent, the court holds a separate hearing to issue a disposition order, which can range from commitment to a juvenile correctional facility or therapeutic out-of-home placement to probation, community service, restitution, or release (Mendel; Puzzanchera).

20 This article uses "prevention" to mean both interventions that work with youth who are involved in the juvenile justice system, to reduce the likelihood of future delinquency, and programs designed to prevent initial delinquency among youth who are at risk.

${ }^{21}$ See note two for information about CSPV.

${ }^{22}$ Seven experts in the field of violence prevention serve on the Advisory Board.

${ }^{23}$ See the cited references of go to http:// www.fftinc.com for additional information on FFT.

${ }^{24}$ Refer to Thomas L. Sexton and James F. Alexander (2000) for more information on the outcomes of not only the cited clinical trials but also comparison studies conducted in 1985, 1988, and 1995.

${ }^{25}$ In 1993, D.C. closed the Cedar Knoll facility, which served detained and commit youth, followed by the
D.C. Receiving Home for Children, which served only detained youth, in 1995 (Feldman et al. 2001).

${ }^{26}$ Other services include after-school entichment, mentoring, and substance abuse (DYRS n.d.a).

${ }^{27}$ See note eight.

${ }^{28}$ The D.C. per capita expenditures may be similat to that of other jurisdictions with similar urbanicity and population levels.

${ }^{29}$ Increases in juvenile arrests did not coincide with increases in the city's youth population. Changes in D.C's population of youth ages 10 to 17 , which might have explained some of the increase in juvenile arrests, did not increase during this period. The U.S. Census Bureau's estimates based on the 2000 census suggest a small decrease (less than 1 percent) in this population during the 2000 to 2005 period (U.S. Census Bureau 2005).

${ }^{30}$ CaIculated using MPD arrest statistics and population data from the U.S. Census Bureau (2005).

${ }^{31}$ City-level, tather than county-level, statistics would provide a more appropriate comparison of trends in these tates because of the often large geographic size of counties and the potential vatiation in arrest rates across communities within counties. However, juvenile arrest rates are available through the FBI Statistics database for some cities in only three states: Maryland, Missouri, and Virginia. Hence, county-level statistics are used as proxies of trends in major cities.

${ }^{32}$ This estimate also includes arrests for narcotic drug laws $(9,323)$, release violations $(4,003)$, and prostitution and commercialized vice $(1,942)$ (MPD 2007).

${ }^{33}$ The FBI's VCI includes not only robbery but also aggravated assault, forcible rape, and murder and nonnegligent manslaughter. The MPD reports arrests for "tape/sexual abuse," which is used for this estimate (MPD 2007).

${ }^{34}$ The Youth Services Administration, which existed within D.C.'s Department of Human Services, administered juvenile justice services prior to DYRS's establishment (NCJJ 2006a). 
${ }^{35}$ A crime emergency declaration empowers the Chicf to suspend D.C.'s contractual scheduling agreements with the Fraternal Order of Police (Ramsey 2006).

${ }^{36}$ The American Civil Liberties Union was among those condemning efforts to change curfew hours or increase and add more cameras, calling it "a feel-good, political gesture" (Montgomery and Stewart 2006, 9 10).

${ }^{37}$ For example, the Act required that Mayor Williams provide the D.C. Council with biweekly crime briefings and Crime Emergency Plans for each police district.

${ }^{38}$ D.C. Act $16-446$ mandated that the Chief use and disclose this information to law enforcement to protect public safety (D.C. Council 2006a).

${ }^{39}$ Per diem expenses include the costs of lodging, meals, and incidentals associated with travel.

${ }^{40}$ The DYRS operating budget includes costs for staff salaries and fringe benefits; supplies and materials; energy; communication costs; land, building, and equipment rental; janitorial and security services; occupancy fixed costs; and contractual services (GDC 2006, E-158).

${ }^{41}$ Commitment data are difficult to interpret: single offenses may result in commitments of multiple youth, or multiple commitments of a single youth.

${ }^{42}$ Some of this amount might offset the costs of services youth were previously receiving from other D.C. agencies, which would decrease the savings associated with reduced commitment to DYRS.

43. These statistics for a more current year are not available on the D.C. Department of Corrections website.

${ }^{44}$ Inmate services include costs for serving inmates' personal needs, food services, laundry, and the commissary (GDC 2006, C-48).

${ }^{45}$ Inmate custody includes costs for detaining pre-trial defendants and incarcerating individuals sentenced for misdemeanors (GDC 2006, C-50).

${ }^{46}$ Calculated by adding the budget for inmate services and custody, dividing by the average daily population (3,453 inmates), and then dividing by 365 days.
47 The estimated costs do not include retraining costs due to therapist attrition. As noted later, a sensitivity analysis should include these costs.

${ }^{48}$ This assumes that a monthly calling plan fee is not needed because the service delivery site (e.g., juvenile court, clinic) would have long-distance communication capabilities.

${ }^{49}$ For years three to eight, the FFT cost document does not specify any communication-related costs, but this analysis includes 12 one-hour calls as expected costs.

${ }^{5 n}$ The calculation for the annual salaries of therapists is $\$ 22.06$ per hour multiplied by 40 hours per week multiplied by 52 weeks, although therapists would work fewer than 2,080 hours over the year due to Federal holidays and personal leave, which the amount allocated for fringe benefits would cover.

${ }^{51}$ The calculation for the lead therapist annual salary is $\$ 25.73$ per hour multiplied by 40 hours per week multiplied by 52 weeks, although this individual would work fewer than 2,080 hours over the year due to Federal holidays and personal leave, which the amount allocated for fringe benefits would cover:

${ }^{52}$ The market and merit increase adjustment for a D.C. employee with a performance rating of "meets expectations" or "satisfactory," depending on the rating system used for a particular employee, is 4 percent (D.C. Office of Personnel 2007).

53 Fringe benefits account for any non-salary compensation to therapists such as health insurance, retirement savings, and personal leave. Fringe benefits should also inchude required taxes such as social security and unemployment, as well as disability insurance. The fringe rate is estimated at 19.5 percent using the fringe benefits line item in the 2007 operating budget for DYRS and dividing this by the sum of regular pay (full time and other) (GDC 2006).

${ }^{54}$ Estimated using the percentage of leisure visitors in 2005 (51 percent), projected visitation for 2007 (16.2 million), 2005 average spending per party visit (\$839. including both business and leisure), and local tax revenue generated by travel and tourism (WCTC 2006).

55 The 2005 findings by gender and race are as follows: 40 percent of males and 53 percent of females avoid 
certain places because of crime-related concerns; 47 percent of whites and nonwhites (including blacks) and 50 percent of blacks only reported changing where they visit due to these concerns.

${ }^{56} \mathrm{CV}$ studies are valuable tools for estimating a policy's economic value and more accurately depicting public attitudes toward policies (relative to public opinion polls) because they ask respondents to consider policy benefits and costs (Nagin et al., 6-8). However, some economists question the method's validity because participants may provide higher or lower estimates of their W'T because of the hypothetical nature of the questions and because question wording causes a "framing effect" that may influence participant responses (Friedman 2002, 206).

${ }^{57}$ To recruit participants, the investigators randomly selected Pennsylvania telephone numbers and excluded non-household numbers. Only 44 percent of the sample ( $n=4,200$ ) completed the survey, but participant characteristics, on average, reflected the state's demographics (e.g., gender, tace, income) and the participation rate is similar to that of other $C V$ studies (Nagit et al. 2006, 10-11).

\section{REFERENCES}

Alexander, J.F., and B.V. Parsons. 1973. Short-term family intervention: $A$ therapy outcome study. Journal of Consulting and Clinical Psychology 2: 195-201. Quoted in Thomas L. Sexton and James F. Alexander, "Functional Family Therapy (U.S. Department of Justice, Office of Justice Programs, Office of Juvenile Justice and Delinquency Prevention, 2000), 5.

Aos, Steve, Polly Phipps, Robert Barnoski, and Roxanne Lieb. 2001. The comparative costs and benefits of programs to reduce crime. Washington State Institute for Public Policy, Olympia, WA.

Austin, James, Kelly Dedel Johnson, and Ronald Weitzer. 2005. Alternatives to the secure detention and confinement of juvenile offenders. (NCJ Publication No. 2088044). U.S. Department of Justice, Office of Justice Programs, Office of Juvenile Justice and Delinquency Prevention. http:// ojjdp.ncjrs.org/publications/PubResults.asp\#2005 (accessed February 3, 2007).
Balis, Nate. E-mail to author, 26 January 2007.

Butts, Jeffrey A. 2003. Juvenile crime in Washington, D.C. The Urban Institute, Justice Policy Center. http:// www.urban.org/publications/310910.html (accessed November 5, 2006).

2000. Youth crime drop. The Urban Institute, Justice Policy Center. http://www. urban.org/publications/410246.html (accessed November 5, 2006).

Butts, Jeffrey A., and Howard N. Snyder. 2006. Too soon to tell: Decipbering recent trends in youth violence, Issue Brief \#110. Chapin Hall Center for Children at the University of Chicago, http://www.chapinhall.org/ article_abstract.aspx?ar $=1437$ (accessed March 10, 2007).

Caldwell, Michael F, Michael Vitacco, and Gregory J. Van Rybroek. 2006. Are violent delinquents worth treating? A cost-benefit analysis. Journal of research in Crime and Delinquency 43(2): 148-168.

Canadian Press, "U.S., local police battle Washington crime wave threatening tourism," The Vancouver Sun, 22 July 2006, < http://www.canada.com/ vancouversun/news/travel/story.html?id $=9 \mathrm{a} 6$ 2b43c-2d2d-41e4-91d3-1f286fa85655\&k=3767> (15 December 2006).

Center for the Study and Prevention of Violence (CSPV), Institute of Behavioral Science,

University of Colorado at Boulder. 2006. Functional Family Therapy. Blueprints Model Programs Fact Sheet. http://www.colorado.edu/cspv/publications/factsheets.html\# blueprints (accessed January 19, 2007).

2004a. Blueprints for violence prevention overview. http://www.colorado.edu/cspv/ blueprints/ index.html (accessed January 19, 2007).

2004b. Blueprints model programs selection oriteria. Institute of Behavioral Science, University of Colorado at Boulder. http:/ /www.colorado.edu/ cspv/blueprints/model/ criteria.html (accessed January 19,2007$)$.

Christle, Christine A., C. Michael Nelson, and Kristine Jolivette. 2001. Prevention of antisocial and violent bebav- 
ior in youtb: A reviezy of the literature. http:// www.edjj.org/focus/ prevention/plr.pdf (accessed February 24, 2007).

Christianson, Scott. "Questioning U.S. artest statistics," The Cbristian Science Monitor, 18 January 2006, <http:/ /www.csmonitor.com/2006/0118/p09s01coop.html?s=widep> (5 March 2007).

Cohen, Mark A. 2000. Measuring the costs and benefits of crime and justice. In Measurement and Analysis of Crime and Justice, edited by David Duffee, U.S. Department of Justice, Office of Justice Programs http://www.ncjrs.gov/criminal_justice2000/vol_4/ 04f.pdf(accessed July 15, 2003).

1998. The monetary value of saving a high-risk youth. Journal of Quantitative Criminology 14(1): 5-33.

Council of the District of Columbia (D.C. Council). 2006a. Enbanced Crime Prevention and Abatement Emergency Amendment Act of 2006 (A16-0446). http:// www.dccouncil, washington.dc.us/images/00001/ 20060726114839.pdf (accessed December 26, 2006).

Council of the District of Columbia (D.C. Council). 2006b. Resolution 16-779. http://www. dccouncil. washington.dc.us/images/00001/2006072611 4554.pdf (accessed December 26,2006).

"Crime emergency," Sunday Territorian, 21 July 2006. Access World News (International Edition) Database, Newsbank Inc. (23 December 2006).

D.C. KIDS COUNT Collaborative for Children and Families. 2005. Every kid counts in the

District of Columbia. http://www.dckidscount,org/ public.htm (accessed December 30, 2006).

DeMaranville, Holly. E-mail to author, 30 March 2003.

Department of Youth Rehabilitation Services (DYRS), Government of the District of Columbia. n.d.a. Community-based services, http://dyrs.dc.gov/dyrs/ cwp/view,a,3,q,599140, dytsNav,|34200/asp (accessed November 30, 2006).
Department of Youth Rehabilitation Services (DYRS), Government of the District of Columbia. n.d.b. Secure program. http://dyrs.dc.gov/dyrs/cwp/ view,a,3,q,599154,dyrsNav,|34200|, . asp (accessed November 30, 2006).

District of Columbia Superior Court (D.C. Superior Court). 2006. Annual report to Congress, Family Court 2006, http://www.dccourts.gov/dccourts/superior/family/index.jsp (accessed January 10, 2007).

District of Columbia Department of Corrections. 2007. DC Department of Corrections facts and figures. http://doc.dc.gov/doc/frames.asp?doc $=/$ doc/ $\mathrm{lib} / \mathrm{doc} / \mathrm{populationstats/dcdepartment}$ ofcorrectionsfactsnfiguresjan072.pdf (accessed March 10, 2007)

2003. Statistics and innate demographics. http:/ /doc.dc.gov/doc/cwp/view,a,3,q, 491480.asp (accessed April 21, 2004)

District of Columbia Office of Petsonnel. 2007. Payfor-performance salary increases, http://dcop.dc.gov/ $\mathrm{dcop} /$ frames.asp?doc $=/ \mathrm{dcop} / \mathrm{lib} / \mathrm{dcop} /$ meritpay.flyer.02.05.07.pdf(accessed April 3, 2007).

Elliott, Delbert S. 1998. Prevention programs that work for youth: Violence prevention. Center for the Study and Prevention of Violence. http://www.colorado.edu/ cspv/publications/ papers/pdf/CSPV-012.pdf (accessed April 21, 2004).

Feldman, Lisa, Michael Males, and Vincent Schiraldi. 2001. A tale of two jurisdictions: Youtb crime and detention rates in Maryland \&o the District of Columbia. Building Blocks for Youth. http://www.buildingblocks foryouth.org/dcmd/ (accessed November 5, 2006).

Friedman, Lee S. 2002. The microeconomics of public policy analysis. Princeton: Princeton University Press.

Kopp, Douglass. E-mail to author, 8 June 2004.

Gies, Steve V. 2003. Aftercare services. Juvenile Justice Practice Series. U.S. Department of Justice, Office of Justice Programs, Office of Juvenile Justice and Delinquency Prevention. http://www.ncjrs.gov/ html/ojjdp/201800/contents.html (accessed December 26, 2006) 
Goldenberg, Suzanne. "Widening gap between rich and poor blamed for rise in violence, with 14 murders in two weeks: Fear and loathing on DC's streets as summer crimewave reaches the elite," The Guardian, 20 July 2006. Access World News (International Edition) Database Newsbank Inc. (19 December: 2006).

Government of the District of Columbia (GDC). 2006. FY 2007 proposed budget and financial plan: Volume 2 agency budget chapters. http:// cfo.dc.gov/cfo/cwp/view, a, 1321 , q, 589949 , cfoNav, $33210 \mid$ asp (accessed January 2, 2007).

Greenwood, Peter W., Karyn E. Model, C. Peter Rydell, and James Chiesa. 1998. Diverting children from a life of crime: Measuring costs and benefits. Santa Monica, CA: RAND.

Hansson, K. 1998. Functional Family Therapy replication in Sweden: Treatment outcome with juvenile delinquents. Paper presented to the Eigth Conference on Treating Addictive Behaviots, Santa Fe, NM Quoted in Thomas L. Sexton and James F. Alexander, "Functional Family Therapy (U.S. Department of Justice, Office of Justice Programs, Office of Juvenile Justice and Delinquency Prevention, 2000), 5.

Howell, James C. 2003. Preventing \& reducing juvenile delinquency: A comprehensive framework. Thousand Oaks, CA: Sage Publications, Inc.

Howell, James C., and J. David Hawkins. 1998. Prevention of youth violence. Crimze and Justice 24: $263-315$.

Kashani, Javad H., Michael R. Jones, Kurt M. Bumby, and Lisa A. Thomas. 1999. Youth violence: Psychosocinl risk factors, treatment, prevention, and recommendations. Journal of Emotional and Bebavioral Disorders 7:200-211.

Klein, Allison. "July homicide total rises to 14 in District," The Washington Post, 12 July 2006a, <http:// www.washingtonpost.com/wp-dyn/content/article/2006/07/12/AR20060712 00441.html> (15 December 2006).

"Williams wants $50 \%$ cut in crime: New coalition sets array of methods," The Washington Post, 22. July 2006b. LexisNexis Academic Universe Database, Reed Elsevier Group (19 December 2006).

Klein, N.C., J.F. Alexander, and B.V. Parsons. 1977. Impact of family systems intervention on recidivism and sibling delinquency: $A$ model of primary prevention and program evaluation. Journal of Consulting and Clinical Psycbology 45(3): 469-474. Quoted in Thomas L. Sexton and James F. Alexander, "Functional Family Therapy (U.S. Department of Justice, Office of Justice Programs, Office of Juvenile Justice and Delinquency Prevention, 2000), 5.

McCord, Joan, Cathy Spatz Widom, and Nancy A. Crowell, eds. 2001. Juvenile crime, juvenile justice. National Research Council and Institute of Medicine. Panel on Juvenile Crime: Prevention, Treatment, and Control. Washington, D.C.: National Academy Press.

Mendel, Richard A. 2001. Less cost, more safety: Guiding lights for reform in juvenile justice, American Youth Policy Forum. http://www.aypf.org/publications/ lesscost/pages/full.pdf (accessed July 20, 2004).

2000. Less bype, more belp: Reducing juvenile crime, what works - and what doesn't, American Youth Policy Forum. http://www.aypf.org/publications/ mendel/MendelRep.pdf (accessed July 20, 2004).

Metropolitan Police Department, Office of Youth Violence Prevention (OYVP). n.d. Office of Youth Violence Prevention Activitics. http://mpdc.dc.gov/ $\mathrm{mpdc} / \mathrm{cwp} / \mathrm{view}, \mathrm{a}, 1232, \mathrm{q}$, 541068, mpdcNav_GID,1529.asp (accessed January 1,2007)

Metropolitan Police Department (MPD). 2007a. Criminal justice information systems (CJIS) arrest reports, 01/01/07-3/31/07. http://mpdc.dc.gov/mpdc/ frames.asp?doc $=/ \mathrm{mpdc} / \mathrm{lib} / \mathrm{mpdc} / \mathrm{about} / \mathrm{units} /$ rrd/cjis/cjis_033107.pdf (accessed April 6, 2007).

2007b. Criminal justice information systems (CJIS) arrest reports, 01/01/06-12/31/06. http://mpdc.dc.gov $/ \mathrm{mpdc} / /$ frames.asp?doc $=/$ mpdc/lib/mpdc/about/units/rrd/cjis/ cjis_123106.pdf (accessed January 6, 2007).

2006. Building a safer DC: Metropolitan Police Department statistical report 2001-2005. http://mpdc.dc.gov/mpdc/cwp/view,A, 
1246,Q,555551.asp (accessed December 27, 2006).

2000. Metropolitan Police Department: 1999 annual report. http://mpdc.dc.gov/mpdc/ cwp/view,A,1246,Q,555551.asp (accessed December 27,2006$)$.

Metropolitan Police Department (MPD), Office of Youth Violence Prevention (OYVP). n.d. Office of Youth Violence Prevention programs. http:// $\mathrm{mpdc} \cdot \mathrm{dc} \cdot \mathrm{gov} / \mathrm{mpdc} / \mathrm{cwp} / \mathrm{view}$, a,1232,q,541082,mpdcNav_GID,1529.asp (accessed March 10, 2007).

Miller, Ted R., Deborah A. Fisher, and Mark A. Cohen. 2001. Costs of juvenile violence: Policy implications. Pediatrics 107(1): 1-7. http://pediatrics.aap publications.org/cgi/content/ full/107/1/e3 (accessed July 15, 2003).

Montgomery, Lori and Nikita Stewart, "Mayor takes aim at city's spike in crime," The Washington Post, 18 July 2006. LexisNexis Academic Universe Database, Reed Elsevier Group (19 December 2006).

Nagin, Daniel S., Alex R. Piquero, Elizabeth Scott, and Laurence Steinberg. 2006. Public preferences for rebabilitation versus incarceration of juvenile offenders: Evidence from a contingent valuation survey. University of Virginia Law School (Paper 28). http://law. bepress.com/ uvalwps/olin/art28 (accessed January 5, 2007).

National Center on Education, Disability and Juvenile Justice (EDJJ). 2002. Risk factors, http:// www.edjj.org/prevention/riskFactors.html (accessed March 15, 2003).

National Center on Juvenile Justice (NCJJ). 2006a. District of Columbia. State juvenile justice profiles. http:/ /www.ncjj.org/stateprofiles/ (accessed January 8, 2007).

2006b. Jwvenile arrest rates by offense, sex, and race. http://ojjdp.ncjrs.org/ojstatbb/crime/excel/ JAR_20060908.xls (accessed January 13, 2007).

National Crime Prevention Council (NCPC). 2003. Prevention can be a priority in the midst of fiscal calamity. Washington, D.C.: Author.

Osher, David M., Mary Magee Quinn, Jeffrey M.
Poirier, and Robert B. Rutherford. (2003). Deconstructing the pipeline: Using efficacy and effectiveness data and cost-benefit analyses to reduce minority youth incarceration. In Johanna Wald \& Daniel J. Losen (Issue Eds.). New direction for youth development: Deconstructing the school-to-prison pipeline ( $p p$. 91-120). San Francisco: Jossey-Bass.

Puzzanchera, C., B. Adams, H. Snyder, and W. Kang. 2006. Easy Access to FBI Arrest Statistics 1994-2004, Office of Juvenile Justice and Delinquency Prevention. http://ojjdp.ncjrs.org/ojstatbb/ezaucr/ (accessed November 30, 2006).

Quinn, Mary Magee, and Jeffrey M. Poirier. 2004. Linking prevention research with policy: Examining the costs and outcomes of the failure to prevent emotional and behavioral disorders. In Handbook of Research in Emotional and Behavioral Disorders,edited by

Robert B. Rutherford, Mary Magee Quinn, and Sarup R. Mathur. New York: The Guilford Press.

Ramsey, Charles H. 2006. Testimony of Cbarles H. Ramsey, Chief of Police: Public roundtable on District government's response to the crime emergency. Government of the District of Columbia, Metropolitan Police Department. http://newsroom.dc.gov/show.aspx/agency/ mpdc/section/4/release/9745 (accessed December 5,2006$)$.

Schiraldi, Vincent. 2006. Juvenile crime: Don't believe the hype....believe in hope. http://dyts. dc.gov/ dyrs/cwp/view,A,11,Q,603585.asp (accessed November 30,2006 ).

Sexton, Thomas L., and James F. Alexander. 2002. Functional Family Therapy: Principles of clinical intervethtion, assessment, and implementation. Functional Family Therapy, LLC. Seattle, WA.

2000. Functional Family Therapy. U.S. Department of Justice, Office of Justice Programs, Office of Juvenile Justice and Delinquency Prevention. http://www.ncjes. gov/html/ojjdp/ jjbul2000_12_4/contents.html (accessed November 26, 2006).

Snyder, Howard N., and Melissa Sickmund. 2006. Juvenile offenders and victims: 2006 national report. U.S. Department of Justice, Office of Justice Pro- 
grams, Office of Juvenile Justice and Delinquency Prevention. http://ojjdp.ncjrs.org/ojstatbb/ n.2006/index.html (accessed November 26, 2006).

Snyder, Howard N. 2006. Juvenile artests 2004. (NCJ Publication No. 214563). U.S. Department of Justice, Office of Justice Programs, Office of Juvenile Justice and Delinquency Prevention. http:// www.ncjrs.gov/pdffiles1/ojjdp/214563.pdf (accessed March 1, 2007).

2002. Juvenile arrests 2000. (NCJ Publication No. 191729). U.S. Department of Justice, Office of Justice Programs, Office of Juvenile Justice and Delinquency Prevention. http://www.ncjts.gov/ pdffiles1/ojjdp/191729.pdf (accessed November 26, 2006).

1997. Juvenile arrests 1995. (NCJ Publication No. 163813). U.S. Department of Justice, Office of Justice Programs, Office of Juvenile Justice and Delinquency Prevention. Washington, D.C.

Sprague, J, and H. Walker, 2000. Early identification and intervention for youth with antisocial and violent behavior. Exceptional Children 66(3): 367-379.

Stahl, Anne L. 2001. Delinquency cases in juvenile court, 2002. (OJJDP Fact Sheet \#02). U.S. Department of Justice, Office of Justice Programs, Office of Juvenile Justice and Delinquency Prevention. http:/ /ojjdp.ncjrs.org/ojstatbb/publications/ statbb.asp?ID= T36\#2006 (accessed January 1, 2007).

Stahl, Anne. L., Charles Puzzanchera, Anthony Sladky, Terrence A. Finnegan, Nancy Tierney, and Howard N. Snyder. 2005. Juvenile court statistics 2002, National Center for Juvenile Justice. http://www.ncjrs.gov/ pdffiles1/ojidp/216251.pdf (accessed March 23, 2007).

Staunton, Denis. "Washington's exclusive neighborhoods now targets of crime," Irish Times, 15 July 2006. Access World News (International Edition) Database, Newsbank Inc. (19 December 2006).

"U.S. capital introduces curfew after crime wave," Agence France-Presse, 21 July 2006. Access World News (International Edition) Database Newsbank Inc. (19 December 2006).
U.S. Census Bureau. 2005. State population estimates. http://www.census.gov/popest/states/asth/ (accessed January 2, 2007).

U.S. Census Bureau, Population Estimates Program, Population Division. 2001. Census 2000 PHC-T-4. Ranking tables for counties: 1990 and 2000. Table 2: Counties ranked by population. http:// www.census.gov/population/cen2000/phc-t4/ tab02.pdf (accessed March 17, 2007).

2000. Population estimates for the U.S., regions, divisions, and states by 5 -year age groups and sex: Time series estimates, July 1, 1990 to July 1 , 1999 and April 1, 1990 census population counts. http://www.census.gov/popest/archives/1990s/ ST-99-08.txt (accessed December 28, 2006).

U.S. Department of Justice, Federal Bureau of Investigation (FBI), Uniform Crime Reporting Program. 2006. Crime in the United States 2005: Clearances. http://www.fbi.gov/ucr/ 05cius/ offenses/clearances/index.html\#figure (accessed March 17, 2007).

2006. Preliminary annual crime report: January through June. http://www.fbi.gov/ucr/ prelim06/table1.htm (accessed March 17, 2007).

U.S. Department of Justice, Office of Justice Programs, Bureau of Justice Statistics (BJS). 2006. Justice expenditure and employment in the United States, 2003. http://www.ojp.usdoj.gov/bjs/pub/pdf/ jeeus03.pdf (accessed January 15, 2007).

2005. Sourcebook of criminal justice statistics, 2003. http://www.albany.edu/ sourcebook/ (accessed December 23, 2006).

1996. Sourcebook of criminal justice statistics, 1995. http:/ /www.albany.edu/source book/ archive.html (accessed December 23, 2006).

U.S. Department of Justice, Office of Justice Programs, Office of Juvenile Justice and Delinquency Prevention (OJJDP). (n.d.). Juvenile justice reform initiatives in the states: 1994-96. http://ojjdp.ncjts.org/ pubs/reform/ch2_b.html (accessed March 22, 2003).

U.S. Department of Labor, Bureau of Labor Statistics. 2005. Occupational Employment and Wage 
Estimates, Bureau of Labor Statistics. http:// www.bls.gov/oes/current/oes_dc.htm (accessed November 30, 2006).

Verizon 2007. Verizon 5 cent package plan. https:// www22.verizon.com/ForYourHome/sas/ sas_LongDistance.aspx (accessed January 27, 2007).

Vito, Gennaro F., Richard Tewksbury, and Deborah G. Wilson. 1998. The juvenile justice system: concepts and issues. Prospect Heights, IL: Waveland Press, Inc.

Washington, Adrienne. "City crime wave or" public health emergency?" The Wasbington Times, 21 July 2006, <http://www.washingtontimes.com/metro/ 20060720-105058-8571 r.htm> (15 December 2006).

Washington, DC Convention and Tourism Corporation (WCTC). 2006. 2005 visitor statistics. http:// www.washington.org/UploadedFiles/ ResearchStatistics/ACF444.pdf (accessed December 15, 2006).

Williams, Anthony A., and Charles H. Ramsey, 2006. Impact of the 2006 crime emergency in the District of Columbia. http://newstoom.dc.gov/file.aspx/release/ 9745/Crime\%20 Emergency\%20Impact.pdf (accessed December 15, 2006). 


\section{APPENDIX}

\section{Figure 1: Per Capita Justice System ExPENDitures IN THE UNITED STATES 1982-2003, Total AND BY TYPE OF JUSTICE ACTIVITY}

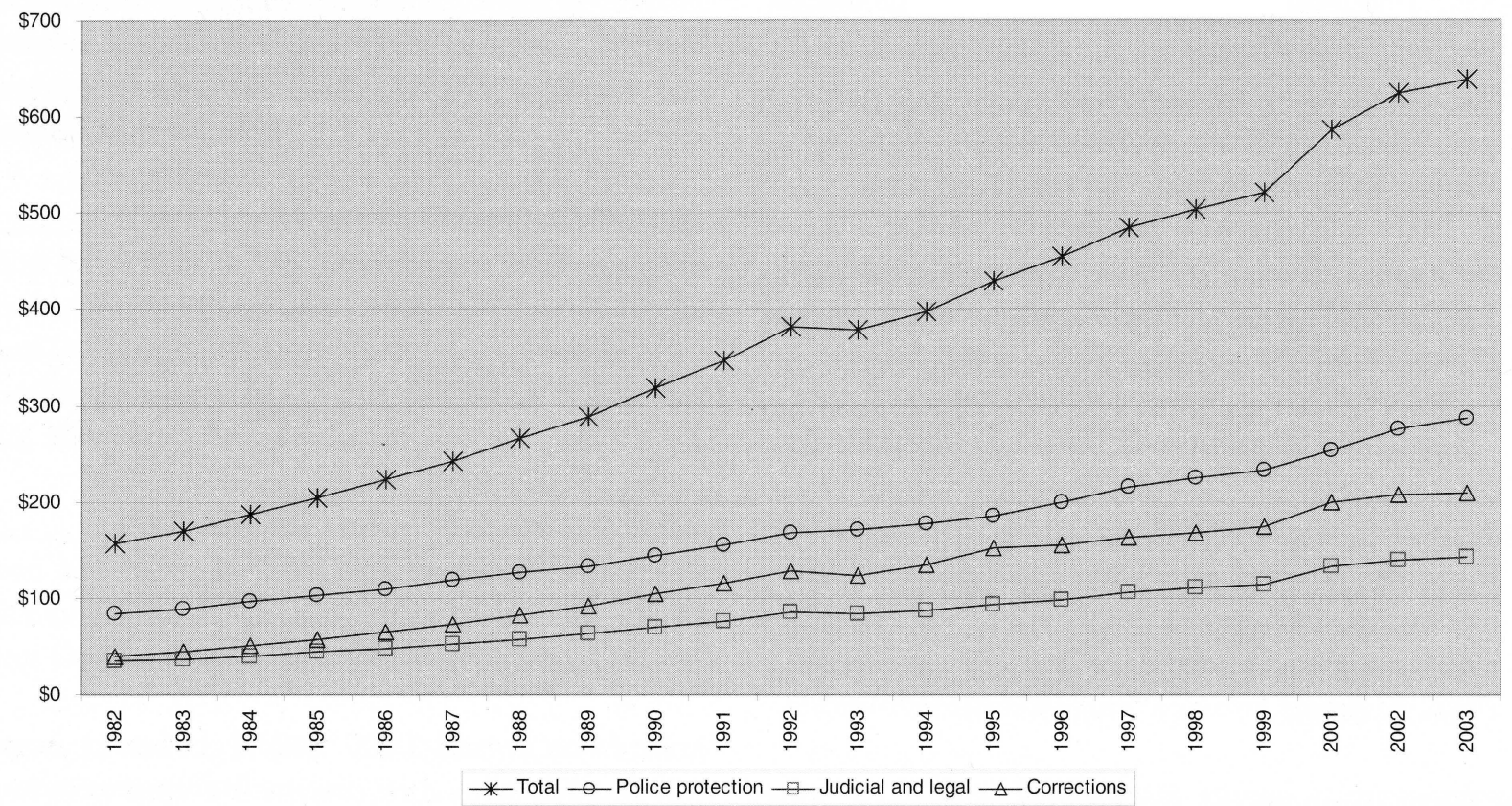

Source: Data for 1982 to 2001 from U.S. Department of Justice, Office of Justice Programs, Bureau of Justice Statistics. Sourcebook of Criminal Justice Statistics, 2003. (Washington, D.C.: Author, 2005), Table 1.7. Data for 2002 and 2003 from U.S. Department of Justice, Office of Justice Programs, Bureau of Justice Statistics. Justice Expenditure and Employment in the United States, 2003. (Washington, D.C.: Author, 2006), 9.

TABLE 1: NUMBER OF JUVENILE ARRESTS IN THE UNITED STATES, 1995-2004

\begin{tabular}{|c|c|c|c|}
\hline \multirow[b]{2}{*}{ Most Serious Offense } & \multicolumn{3}{|c|}{ Number of Juvenile Arrests in the U.S.: 1995, 2000, 2004} \\
\hline & 1995 & 2000 & 2004 \\
\hline Violent Crime Index & 147,700 & 98,900 & 91,100 \\
\hline Homicide/manslaughter & 3,300 & 1,200 & 1,110 \\
\hline Robbery & 55,500 & 26,800 & 25,340 \\
\hline Aggravated assault & 83,500 & 66,300 & 60,450 \\
\hline Property Crime Index & 737,400 & 518,800 & 452,300 \\
\hline Burglary & 135,800 & 95,800 & 81,600 \\
\hline Larceny-theft & 510,600 & 363,500 & 323,500 \\
\hline Nonindex & $1,859,900$ & $1,751,700$ & $1,658,600$ \\
\hline Other (simple) assaults & 215,700 & 236,800 & 249,900 \\
\hline Total & $2,745,000$ & $2,369,400$ & $2,202,000$ \\
\hline $\begin{array}{l}\text { Note: Only selected types of Vio } \\
\text { included. Therefore, total arrests } \\
\text { estimated by OJJDP using arrest } \\
\text { from Howard N. Snyder, Juvenil } \\
\text { Delinquency, 1997), 2. Data for } \\
\text { D.C.: Office of Juvenile Justice a } \\
\text { Juvenile Arrests 2004, (Washing }\end{array}$ & $\begin{array}{l}\text { ent Crime Index } \\
\text { do not equal the } \\
\text { and population d } \\
\text { Arrests } 1995 \text {, ( } \\
000 \text { from Howa } \\
\text { d Delinquency, }\end{array}$ & $\begin{array}{l}\text { Crime Index, a } \\
\text { the types of arres } \\
\text { outh ages } 10 \text { to } 1 \\
\text { ton, D.C.: Office } \\
\text { yder, Juvenile A } \\
\text { 3ata for } 2004\end{array}$ & $\begin{array}{l}\text { index arrests are } \\
\text {. Arrest rates are } \\
\text { ees: Data for } 1995 \\
\text { enile Justice and } \\
000, \text { (Washington, } \\
\text { oward N. Snyder, } \\
\text { ncy, 2006), 3. }\end{array}$ \\
\hline
\end{tabular}




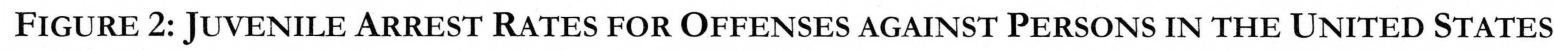
1980-2004

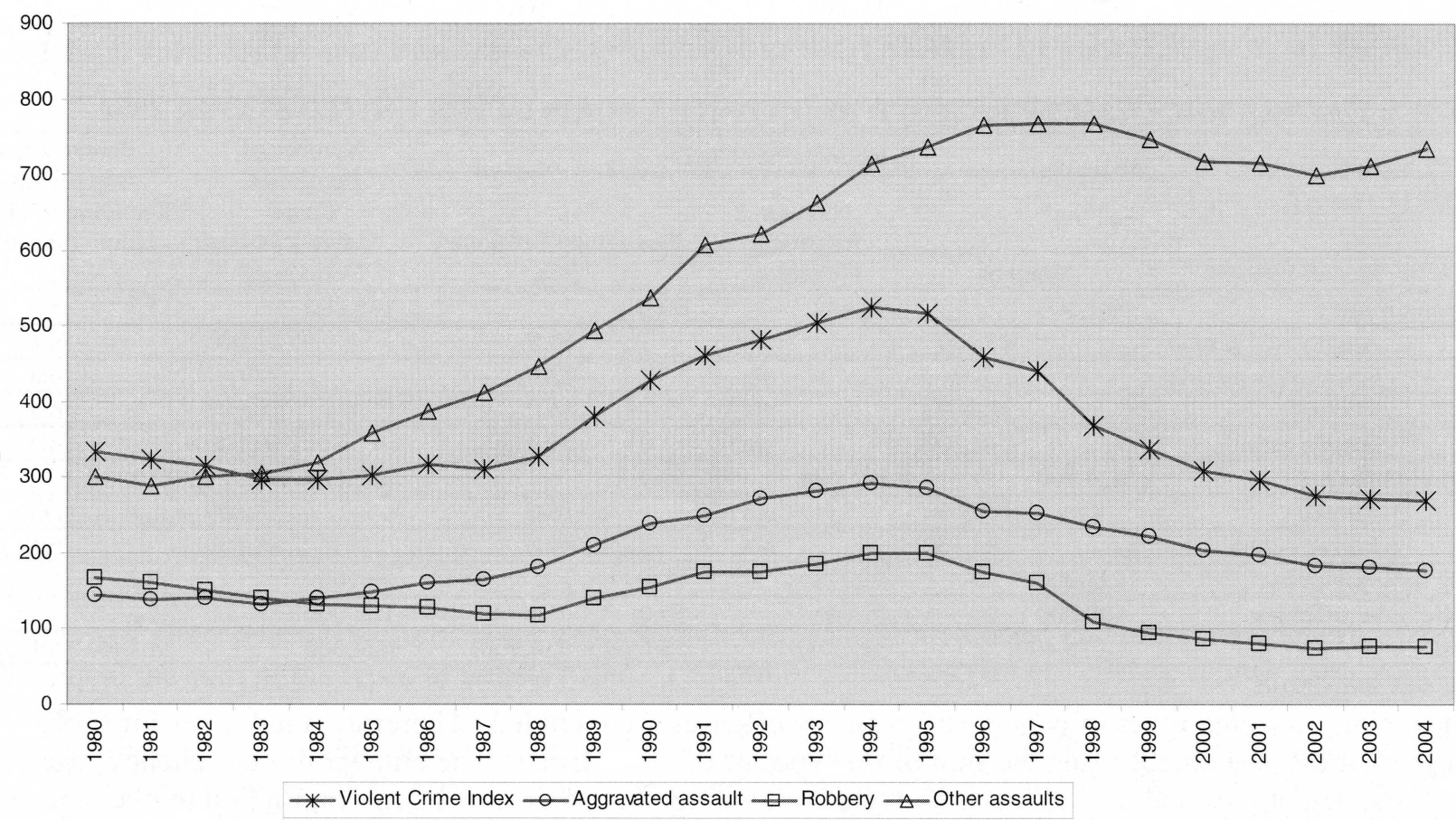

Note: Rates are calculated as arrests of youth ages ten to seventeen per 100,000 youth ages ten to seventeen. The Violent Crime Index includes aggravated assault and robbery, as well as forcible rape and murder. Source: Data from National Center for Juvenile Justice, Juvenile Arrests by Offense, Sex, and Race, (Washington, D.C.: NCJJ, 2006b).

Figure 3: JUVEnile ARrest RATES FOr Property OfFENSES IN THE UNITED STATES 1980-2004

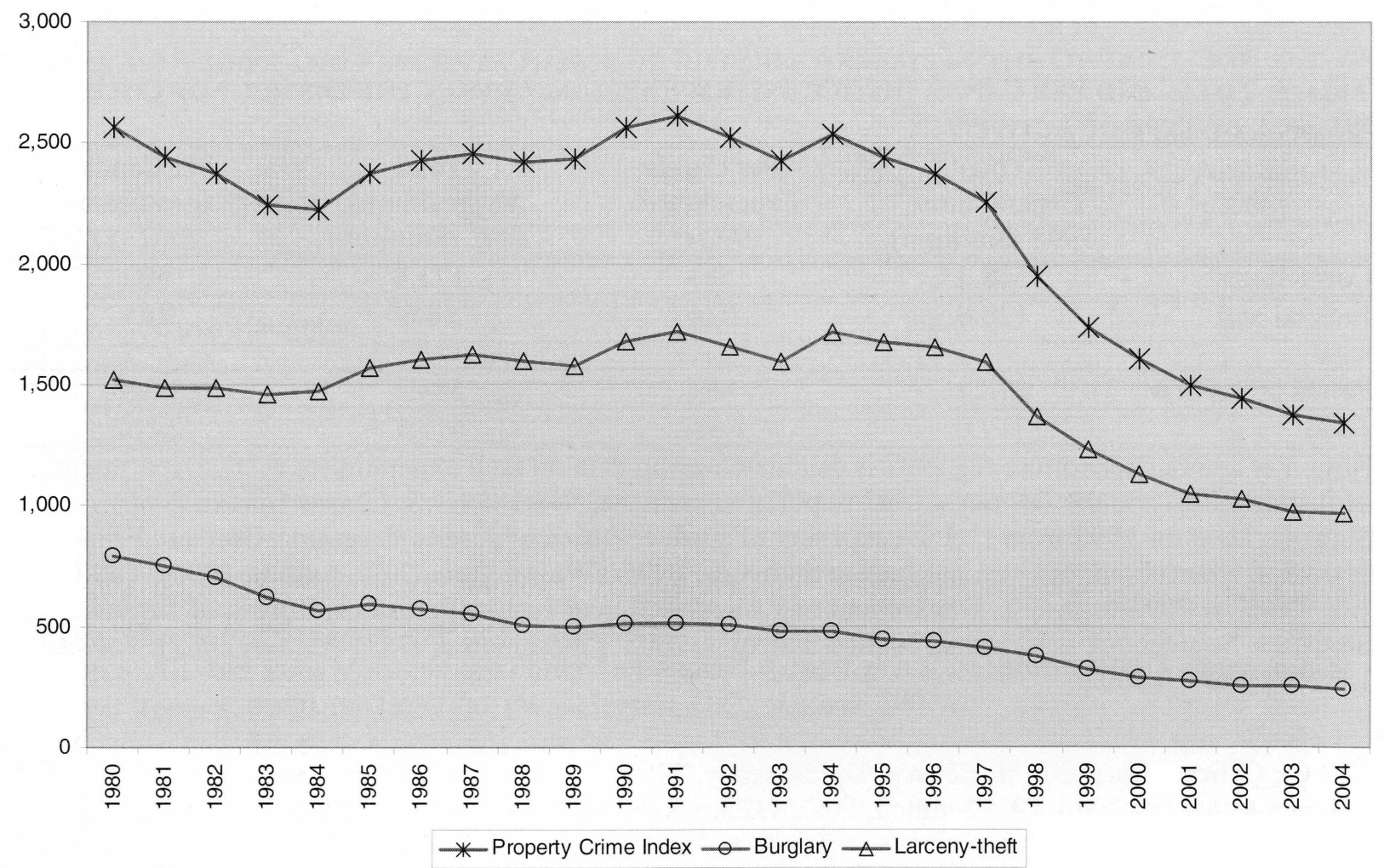

Note: Rates are calculated as arrests of youth ages ten to seventeen per 100,000 youth ages ten to seventeen. Source: Data from National Center for Juvenile Justice, Juvenile Arrests by Offense, Sex, and Race, (Washington, D.C.: NCJJ, 2006b). 
TABLE 2: Delinquency CASES Processed By JUVENILE COURTS IN THE UNITED STATES, 2002

\begin{tabular}{|c|c|c|c|c|c|}
\hline \multirow[b]{2}{*}{ Most Serious Offense } & \multicolumn{3}{|c|}{ Delinquency Cases } & \multirow{2}{*}{$\begin{array}{l}\text { Number of } \\
\text { Petitioned } \\
\text { Cases } \\
\text { Adjudicated } \\
\text { Delinquent } \\
\end{array}$} & \multirow{2}{*}{$\begin{array}{c}\text { Percentage of } \\
\text { Adjudications } \\
\text { Resulting in Out-of- } \\
\text { Home Placement } \\
(\%)\end{array}$} \\
\hline & Number & $\begin{array}{l}\text { Number } \\
\text { Involving } \\
\text { Detention }\end{array}$ & $\begin{array}{c}\text { Percentage Petitioned } \\
(\%)\end{array}$ & & \\
\hline Person offenses & 387,500 & 95,642 & 60.0 & 145,800 & 25.7 \\
\hline Aggravated assault & 47,400 & $\mathrm{n} / \mathrm{a}$ & 69.0 & 21,900 & $\mathrm{n} / \mathrm{a}$ \\
\hline Criminal homicide & 1,700 & $\mathrm{n} / \mathrm{a}$ & 82.0 & 800 & $\mathrm{n} / \mathrm{a}$ \\
\hline Property offenses & 624,900 & 105,536 & 55.0 & 233,600 & 22.8 \\
\hline Burglary & 100,000 & $\mathrm{n} / \mathrm{a}$ & 78.0 & 58,300 & $\mathrm{n} / \mathrm{a}$ \\
\hline Larceny-theft & 284,400 & $\mathrm{n} / \mathrm{a}$ & 44.0 & 83,600 & $\mathrm{n} / \mathrm{a}$ \\
\hline Drug law violations & 193,200 & 36,278 & 61.0 & 79,100 & 18.2 \\
\hline Public order offenses & 409,800 & 89,046 & 59.0 & 166,000 & 24.3 \\
\hline Total & $1,615,400$ & 329,800 & $58.0(N=934,900)$ & 624,500 & $23.1(\mathrm{~N}=144,000)$ \\
\hline
\end{tabular}

n/a: not available

Notes: Only selected types of person and property offenses are included. Therefore, total cases for each category of offense do not equal the sum of the types of offenses listed. The number of delinquency cases involving detention is calculated using source data (total number of detained cases multiplied by the percentage of these cases in each offense category). The total number of cases involving detention is slightly greater than the sum of the major offense categories because the source percentages equal 99 percent. The percentage of dispositions resulting in out-of-home placement is also calculated by using source data (total number of cases resulting in this placement multiplied by the percentage of these cases in each offense category).

Source: All data from Anne L. Stahl et al., Juvenile Court Statistics 2002, (Washington, D.C.: National Center for Juvenile Justice, 2005), 7, 26, 31, 39, 44.

Table 3: Total and Per Capita Justice System Expenditures in the District of Columbia 1992-2002, BY TYPE OF ACTIVITY

\begin{tabular}{lcccc}
\hline & $\begin{array}{c}\text { Total } \\
\text { Expenditures, } \\
1992(\text { \$million) }\end{array}$ & $\begin{array}{c}\text { Per Capita } \\
\text { Expenditures, } \\
1992(\$)\end{array}$ & $\begin{array}{c}\text { Total } \\
\text { Expenditures, } \\
2002(\$ \text { million) }\end{array}$ & $\begin{array}{c}\text { Per Capita } \\
\text { Expenditures, } \\
2002(\$)\end{array}$ \\
\hline Corrections & 318.3 & 581 & 173.8 & 609 \\
\hline $\begin{array}{l}\text { Judicial and } \\
\text { legal }\end{array}$ & 128.0 & 234 & 58.6 & 205 \\
\hline Police protection & 272.7 & 497 & 384.7 & 1,348 \\
\hline Total & 719.0 & 1,312 & 617.1 & 2,162 \\
\hline
\end{tabular}

Note: Per capita expenditure for 1992 is calculated using data on total expenditures (U.S. Department of Justice 1996) and the District's 1992 population estimate, 548,183 (U.S. Census Bureau 2000). Sources: Data for 1992 from U.S. Department of Justice, Office of Justice Programs, Bureau of Justice Statistics. Sourcebook of Criminal Justice Statistics, 1995. (Washington, D.C.: Author, 1996), Table 1.6. Data for 2002 from U.S. Department of Justice, Office of Justice Programs, Bureau of Justice Statistics. Sourcebook of Criminal Justice Statistics, 2003. (Washington, D.C.: Author, 2005), Tables 1.6.2002 and 1.8.2002. 
Table 4: Number and Percent Change of Juvenile Arrests in the District, by Index and NON-INDEX CRIMES, 1995- 2002

\begin{tabular}{|c|c|c|c|}
\hline \multicolumn{3}{|c|}{ Number of Juvenile Arrests in the District } & \multirow{2}{*}{$\begin{array}{c}\text { Percent } \\
\text { Change in } \\
\text { Arrests (1995- } \\
\text { 2002) }\end{array}$} \\
\hline 1995 & 1999 & 2002 & \\
\hline 639 & 881 & 376 & -41.2 \\
\hline 320 & 188 & 151 & -52.8 \\
\hline 73 & 36 & 39 & -46.6 \\
\hline 13 & 1 & 10 & -23.1 \\
\hline 76 & 50 & 55 & -27.6 \\
\hline 299 & 114 & 117 & -60.9 \\
\hline 2,359 & 2,037 & 2,203 & -6.6 \\
\hline 260 & 186 & 267 & 2.7 \\
\hline 3,916 & 2,918 & 2,579 & -34.1 \\
\hline
\end{tabular}

Notes: Only selected types of index and non-index arrests are included. Therefore, total arrests do not equal the sum of the types of arrests listed. The author calculated percent change figures using source data.

Sources: For 1995, the source is Puzzanchera et al., Easy Access to FBI Statistics 1994-2004, (Washington, D.C.: Office of Juvenile Justice and Delinquency Prevention, 2006). For 1999, the source is Metropolitan Police Department, Metropolitan Police Department: 1999 Annual Report, (Washington, D.C.: Author, 2000), 24. For 2002, the source is Metropolitan Police Department, Building a Safer DC: Metropolitan Police Department Statistical Report 2001-2005, (Washington, D.C.: Author, 2006), 42.

TABle 5: Number aNd PERcent Change OF JUVENILE ARRESTS IN THE District, 2005 aND 2006 Number of Juvenile Arrests Percent of Total $\begin{array}{ccc}\text { Number of Juvenile Arrests } & \text { Percent } & \begin{array}{c}\text { Percent of Total } \\ \text { Juvenile and Adult }\end{array} \\ \text { Change in Arrests } & \text { Jund }\end{array}$

\begin{tabular}{lcccc} 
Type of Crime & 2005 & 2006 & $(2005-06)$ & $\begin{array}{c}\text { Arrests } \\
(2006)\end{array}$ \\
\hline Aggravated assault & 200 & 211 & 5.5 & 12.1 \\
\hline Burglary & 41 & 51 & 24.4 & 12.8 \\
\hline Homicide/manslaughter & 2 & 6 & 200.0 & 5.8 \\
\hline Larceny-theft & 93 & 104 & 11.8 & 8.8 \\
\hline Other assaults & 369 & 432 & 17.1 & 9.1 \\
\hline Other felonies & 300 & 337 & 12.3 & 18.8 \\
\hline Other misdemeanors & 488 & 627 & 11.4 & 28.5 \\
\hline Robbery & 211 & 252 & 19.4 & 36.7 \\
\hline Weapons & 154 & 166 & 7.8 & 10.4 \\
\hline Total Arrests & 2,935 & 3.297 & 12.3 & 6.1 \\
\hline
\end{tabular}

Note: The robbery category excludes carjacking.

Source: All data from Metropolitan Police Department. Criminal Justice Information Systems (CJIS) Arrest Reports, 01/01/06-12/31/06, (Washington, D.C: Author, 2007a). 
TABle 6: JUVENILE ARREST RATE IN 2000 and CHANGE IN JUVENILE ARrest RATE 2000-2004, BY URBAN AREA

\begin{tabular}{|c|c|c|c|c|}
\hline \multirow{2}{*}{\multicolumn{2}{|c|}{$\begin{array}{l}\text { Cliange in juvenile } \\
\text { arrest rate, 2000-2004 }\end{array}$}} & \multicolumn{3}{|c|}{$\begin{array}{l}\text { Arrest rate of individuals under age } 18 \text {, } \\
\text { per } 100,000 \text { individuals age } 10 \text { to } 17 \text { (2000) }\end{array}$} \\
\hline & & $<7,200$ & $7,200-9,600$ & $>9,600$ \\
\hline \multirow{2}{*}{ Increase } & $\begin{array}{l}22.0 \text { to } 46.0 \\
\text { percent }\end{array}$ & $\begin{array}{l}\text { Bexar County (San Antonio), TX } \\
\text { Davidson County (Nashville), TN* } \\
\text { Washington, D.C.* }\end{array}$ & & $\begin{array}{l}\text { Baltimore County, MD* } \\
\text { Philadelphia County, PA }\end{array}$ \\
\hline & $\begin{array}{l}\text { Less than } \\
11 \text { percent }\end{array}$ & $\begin{array}{l}\text { Dallas County, TX } \\
\text { Mecklenburg County (Charlotte), } \\
\text { NC* }^{*}\end{array}$ & $\begin{array}{l}\text { Hartford County, CT* } \\
\text { Oklahoma County, OK }\end{array}$ & Baltimore City, MD \\
\hline \multirow{3}{*}{ Decrease } & $\begin{array}{l}\text { Less than } \\
15 \text { percent }\end{array}$ & $\begin{array}{l}\text { Harris County (Houston) TX* } \\
\text { Los Angeles County, CA } \\
\text { Providence County, RI } \\
\text { Richmond City, VA } \\
\text { Santa Clara County, CA } \\
\text { St. Louis City, MO } \\
\text { Suffolk County (Boston), MA } \\
\text { Wayne County (Detroit), MI }\end{array}$ & $\begin{array}{l}\text { Multnomah County (Portland), OR* } \\
\text { New Haven County, CT } \\
\text { San Bernardino County, CA } \\
\text { United States }\end{array}$ & $\begin{array}{l}\text { Marion County (Indianapolis), IN } \\
\text { Salt Lake County, UT } \\
\text { Tarrant County (Fort Worth), TX* }\end{array}$ \\
\hline & $\begin{array}{l}15.0 \text { to } 29.9 \\
\text { percent }\end{array}$ & $\begin{array}{l}\text { Hudson County (Jersey City), NJ } \\
\text { Montgomery County, MD } \\
\text { Pierce County (Tacoma), WA } \\
\text { Sacramento County, CA } \\
\text { San Diego County, CA } \\
\text { Worcester County, MA }\end{array}$ & $\begin{array}{l}\text { Anchorage Borough, AK } \\
\text { Arlington County, VA* } \\
\text { Maricopa County (Phoenix), AZ } \\
\text { New Castle County (Wilmington), } \\
\text { DE } \\
\text { Pulaski County (Little Rock), AR } \\
\text { Tulsa County, OK } \\
\text { Virginia Beach City, VA } \\
\end{array}$ & $\begin{array}{l}\text { Charleston County, SC } \\
\text { Douglas County (Omaha), NE } \\
\text { El Paso County, TX } \\
\text { Honolulu County, HI } \\
\text { Jackson County (Kansas City), MO } \\
\text { New York County, NY }\end{array}$ \\
\hline & $\begin{array}{l}30.0 \text { to } 44.0 \\
\text { percent }\end{array}$ & $\begin{array}{l}\text { Franklin County (Columbus), } \mathrm{OH} \\
\text { Prince George's County, MD } \\
\text { San Francisco County, CA }\end{array}$ & $\begin{array}{l}\text { Bronx County, NY } \\
\text { Fresno County, CA } \\
\text { Kern County (Bakersfield), CA } \\
\text { Kent County (Grand Rapids), MI } \\
\text { Kings County (Brooklyn), NY } \\
\text { Queens County, NY }\end{array}$ & $\begin{array}{l}\text { Clark County (Las Vegas), NV } \\
\text { Denver County, CO } \\
\text { Hennepin County (Minneapolis), } \\
\text { MN }\end{array}$ \\
\hline
\end{tabular}

Notes: Changes in juvenile arrest rates are calculated using data on juvenile arrest rates in 2000 and 2004.

Due to limitations in available data, change is calculated over a different period in five cases: Arlington County (2001-2004), the District (2000-2006), Kent County (1999-2004), Mecklenburg County (20002003), and Suffolk County (2000-2002). The rate of juvenile arrests for crimes on the Violent Crime Index increased over the 2000-2004 period in the areas marked with an asterisk.

Sources: Juvenile arrest rates for all areas except the District come from Puzzanchera et al., Easy Access to FBI Statistics 1994-2004, (Washington, D.C.: Office of Juvenile Justice and Delinquency Prevention, 2006). The arrest rate for the District is calculated using data on the number of total juvenile arrests from the Metropolitan Police Department and the population of individuals age 10 to 17 from the U.S. Census Bureau (2005). The District's 2005 population data are used as a proxy for 2006, which were not available from the Census.

TABLE 7: NUMBER OF JUVENILE OFFENDERS IN RESIDENTIAL CUSTODY FACILITIES AND RATE PER 100,000 JUVENILES IN THE DISTRICT (AGES 10 TO 18), 1975-2003

\begin{tabular}{lccccc} 
& 1975 & 1985 & 1997 & 2001 & 2003 \\
\hline Number & 654 & 281 & 264 & 171 & 285 \\
\hline Rate & - & - & 578 & 369 & 625 \\
\hline
\end{tabular}

Sources: Data for 1975 and 1985 from U.S. Department of Justice, Office of Justice Programs, Bureau of Justice Statistics. Sourcebook of Criminal Justice Statistics, 1994. (Washington, D.C.: Author, 1995), Table 6.9. Data for 1997, 2001, and 2003 from U.S. Department of Justice, Office of Justice Programs, Bureau of Justice Statistics. Sourcebook of Criminal Justice Statistics, 2003. (Washington, D.C.: Author, 2005), Table 6.9.2003. 
TABLE 8: SUMmARY OF ANTICIPATED EFFECTS OF FUNCTIONAL FAMILY THERAPY: BENEFITS, COST', AND UNCERTAIN OUTCOMES

\begin{tabular}{|c|c|}
\hline Predicted Benefits & Predicted Costs \\
\hline \multicolumn{2}{|c|}{ Government of the District of Columbia } \\
\hline $\begin{array}{l}\text { - Decreased costs for the Committed } \\
\text { Services program of the District's } \\
\text { Department of Youth Rehabilitation } \\
\text { Services } \\
\text { - Decreased costs for the Detained } \\
\text { Services program of the District's } \\
\text { Department of Youth Rehabilitation } \\
\text { Services } \\
\text { - Decreased costs for the Medical } \\
\text { Services program of the District's } \\
\text { Department of Youth Rehabilitation } \\
\text { Services } \\
\text { - Decreased cost of incarcerating } \\
\text { juvenile offenders in correctional } \\
\text { facilities } \\
\text { - No decrease in tax revenue due to } \\
\text { perceptions of Washington as a } \\
\text { dangerous city }\end{array}$ & $\begin{array}{l}\text { Phase One, Site Certification Training } \\
\text { Activities and Services (including } \\
\text { consultant fees, clinical services } \\
\text { system program, telephone } \\
\text { communication costs, travel expenses } \\
\text { for the consultant and therapists } \\
\text { including airfare, lodging, local } \\
\text { transportation, meals, airport parking) } \\
\text { - Phase Two, Site Certification Training } \\
\text { Activities and Services (including } \\
\text { consultant fees, travel expenses for the } \\
\text { FFT consultant including airfare, } \\
\text { lodging, local transportation, meals, } \\
\text { parking) } \\
\text { Salaries for } 8 \text { therapists } \\
\text { Phase Three, Continuing Education } \\
\text { (including consultant fees, travel } \\
\text { expenses for the FFT consultant } \\
\text { including airfare, lodging, local } \\
\text { transportation, meals, parking) }\end{array}$ \\
\hline
\end{tabular}

Federal Government

- Decreased cost of processing juvenile cases in the District of Columbia Courts (the D.C, courts are funded directly by the Federal government)

\section{Victims of Juvenile Crime}

- Decreased pain and suffering due to fewer violent crimes committed by juveniles

- Decreased loss of personal property due to decreased juvenile crime

- Decreased loss of life due to fewer homicides committed by juveniles

- Decreased medical costs

- Various benefits associated with the decreased likelihood of recidivism, including decreased involvement with Juvenile Offenders juvenile justice system

- Decreased commitment to juvenile justice system may increase time in school

- Time commitment to participating in therapy 
Families of Victims of Juvenile Delinquency

- Decreased emotional pain due to injury to loved one or loss of loved one's life, due to fewer juvenile delinquent acts

- Decreased emotional pain Families of Juvenile Offenders

District Employers of Crime Victims

- Improved productivity due to fewer victims of juvenile crime

District of Columbia General Public (the community)

- Improved quality of life due to increased sense of well-being and safety

- Opportunity cost of not funding other programs/services with money used to fund FFT

Health and Property Insurance Companies

- Reduced payments to victims for their crime-related medical expenses

- Reduced payments to victims for their crime-related property losses

\section{Uncertain Outcomes}

- Improved econornic activity due to improved perceptions of safety for both residents and visitors, benefiting the District government with increased tax revenue and local business with increased revenues

- Decreased police-related costs due to decreased likelihood of future crime emergencies

- Decreased Mayor and D.C. Councilrelated costs due to decreased likelihood of future crime emergencies

'Committed Services "provides protection, rehabilitation, and skills development services to court-involved ordered youth and their families so that the youth can become self-reliant and lead productive ways" (GDC 2006, E-127).

"Detained Services "provides secure and non-secure supervision, screening, monitoring, and transportation" (GDC 2006, E-128).

${ }^{3}$ Medical Services provides medical services to detained and committed youth (GDC 2006, E-129).

TABLE 9: ANNUAL SAVINGs BEgINNING IN YEAR THREE AND TOTAL SAVINGS (YEARS THREE TO NINE)

\begin{tabular}{lcccc}
\hline \multirow{2}{*}{$\begin{array}{c}\text { Area of } \\
\text { Reduced Costs }\end{array}$} & \multicolumn{2}{c}{ Annual Savings (\$) } & \multicolumn{2}{c}{ Total Savings (\$) } \\
\cline { 2 - 5 } & $\begin{array}{c}\text { With Energy and } \\
\text { Fixed Costs }\end{array}$ & $\begin{array}{c}\text { Without Energy } \\
\text { and Fixed Costs }\end{array}$ & $\begin{array}{c}\text { With Energy and } \\
\text { Fixed Costs }\end{array}$ & $\begin{array}{c}\text { Without Energy } \\
\text { and Fixed Costs }\end{array}$ \\
\hline $\begin{array}{l}\text { Detained youth } \\
\text { services }\end{array}$ & 837,858 & 795,965 & $5,865,006$ & $41,055,042$ \\
\hline $\begin{array}{l}\text { Committed youth } \\
\text { services }\end{array}$ & 281,448 & 267,376 & $1,970,136$ & $13,790,952$ \\
\hline $\begin{array}{l}\text { Medical services for } \\
\text { detained and } \\
\text { committed youth }\end{array}$ & 127,602 & 121,222 & & 893,214 \\
\hline $\begin{array}{l}\text { Department of } \\
\text { Corrections }\end{array}$ & unknown & unknown & unknown & unknown \\
\hline \multicolumn{1}{c}{ Total } & $1,246,908$ & $1,184,563$ & $8,728,356$ & $8,291,941$ \\
\hline
\end{tabular}

TABLE 10: FFT ESTIMATED CONSULTANT, TRAVEL, AND LONG-DisTANCE COMMUNICATION COSTS, BY YEAR

\begin{tabular}{cccccc}
\hline & & & \multicolumn{3}{c}{ Communication } \\
\cline { 5 - 6 } Year & $\begin{array}{c}\text { Consultant } \\
\text { Costs }(\$)\end{array}$ & $\begin{array}{c}\text { Travel } \\
\text { Costs }(\$)\end{array}$ & $\begin{array}{c}\text { Number of } \\
\text { Calls }\end{array}$ & $\begin{array}{c}\text { Number of } \\
\text { Minutes }\end{array}$ & Total Costs $(\$)$ \\
\hline 1 & 29,500 & 14,731 & 52 & 3,120 & 156 \\
\hline 2 & 12,000 & 2,270 & 24 & 1,440 & 72 \\
\hline 3 & 5,000 & 652 & 12 & 720 & 36 \\
\hline 4 & 5,000 & 652 & 12 & 720 & 36 \\
\hline 5 & 5,000 & 652 & 12 & 720 & 36 \\
\hline 6 & 5,000 & 652 & 12 & 720 & 36 \\
\hline 7 & 5,000 & 652 & 12 & 720 & 36 \\
\hline 8 & 5,000 & 652 & 12 & 720 & 36 \\
\hline Total & 71,500 & 20,913 & 148 & 8,880 & 444 \\
\hline
\end{tabular}


TABLE 11: ESTIMATED THERAPIST COMPENSATION, BY YEAR

\begin{tabular}{ccccc}
\hline Year & $\begin{array}{c}\text { Lead Therapist } \\
\text { Salary }(\$)\end{array}$ & $\begin{array}{c}\text { Lead Therapist } \\
\text { Fringe Benefits }(\$)\end{array}$ & $\begin{array}{c}\text { Other Therapist } \\
\text { Salary }(\$)\end{array}$ & $\begin{array}{c}\text { Other Therapist } \\
\text { Fringe Benefits }(\$)\end{array}$ \\
\hline 1 & 53,518 & 10,436 & 45,885 & 8,948 \\
\hline 2 & 55,659 & 10,853 & 47,720 & 9,305 \\
\hline 3 & 57,885 & 11,288 & 49,629 & 9,678 \\
\hline 4 & 60,200 & 11,739 & 51,614 & 10,065 \\
\hline 5 & 62,608 & 12,209 & 53,679 & 10,467 \\
\hline 6 & 65,113 & 12,697 & 55,826 & 10,886 \\
\hline 7 & 67,717 & 13,205 & 58,059 & 11,322 \\
\hline 8 & 70,426 & 13,733 & 60,382 & 11,774 \\
\hline Total & 493,127 & 96,160 & 422,795 & 82,445 \\
\hline
\end{tabular}

TABLE 12: TOTAL COSTS, BY YEAR

\begin{tabular}{cccccc}
\hline Year & $\begin{array}{c}\text { Therapist } \\
\text { Compensation }(\$)\end{array}$ & $\begin{array}{c}\text { Consultant } \\
\text { Costs }(\$)\end{array}$ & $\begin{array}{c}\text { Travel } \\
\text { Costs }(\$)\end{array}$ & $\begin{array}{c}\text { Communication } \\
\text { Costs }(\$)\end{array}$ & $\begin{array}{c}\text { Total } \\
\text { Costs }(\$)\end{array}$ \\
\hline 1 & 447,785 & 29,500 & 14,731 & 156 & 492,172 \\
\hline 2 & 465,687 & 12,000 & 2,270 & 72 & 480,029 \\
\hline 3 & 484,322 & 5,000 & 652 & 36 & 490,010 \\
\hline 4 & 503,692 & 5,000 & 652 & 36 & 509,380 \\
\hline 5 & 523,839 & 5,000 & 652 & 36 & 529,527 \\
\hline 6 & 544,794 & 5,000 & 652 & 36 & 550,482 \\
\hline 7 & 566,589 & 5,000 & 652 & 36 & 572,277 \\
\hline 8 & 589,251 & 5,000 & 652 & 36 & 594,939 \\
\hline Total & $4,125,959$ & 71,500 & 20,913 & 444 & $4,218,816$ \\
\hline
\end{tabular}

TABLE 13: SUMMARY OF ESTIMATED ANNUAL BENEFITS AND COSTS

\begin{tabular}{cccc}
\hline Year & $\begin{array}{c}\text { Annual } \\
\text { Benefits }(\$)\end{array}$ & $\begin{array}{c}\text { Annual } \\
\text { Costs }(\$)\end{array}$ & $\begin{array}{c}\text { Net Benefits } \\
\text { (Costs) }(\$)\end{array}$ \\
\hline 1 & 0 & 492,172 & $(492,172)$ \\
\hline 2 & 0 & 480,029 & $(480,029)$ \\
\hline 3 & $1,184,563$ & 490,010 & 694,553 \\
\hline 4 & $1,184,563$ & 509,380 & 675,183 \\
\hline 5 & $1,184,563$ & 529,527 & 655,036 \\
\hline 6 & $1,184,563$ & 550,482 & 634,081 \\
\hline 7 & $1,184,563$ & 572,277 & 612,286 \\
\hline 8 & $1,184,563$ & 594,939 & 589,624 \\
\hline 9 & $1,184,563$ & 0 & $1,184,563$ \\
\hline Total & $8,291,941$ & $4,218,816$ & $4,073,125$ \\
\hline & & & \\
TABLE 14: PRESENT VALUE OF EsTIMATED ANNUAL BENEFITS AND COS' & Annual & Net Benefits \\
\hline Year & Annual & Costs) (\$) \\
\hline 1 & Benefits (\$) & Costs (\$) & $(492,172)$ \\
\hline 2 & 0 & 492,172 & $(448,625)$ \\
\hline 3 & 0 & 448,625 & 606,649 \\
\hline 4 & $1,034,643$ & 427,994 & 551,150 \\
\hline 5 & 966,956 & 415,806 & 499,723 \\
\hline 6 & 903,697 & 403,974 & 452,091 \\
\hline 7 & 844,577 & 392,486 & 407,992 \\
\hline 8 & 789,324 & 381,332 & 367,188 \\
\hline
\end{tabular}


Figure 4: Present Value of Annual Benefits and Costs, Years One to Nine

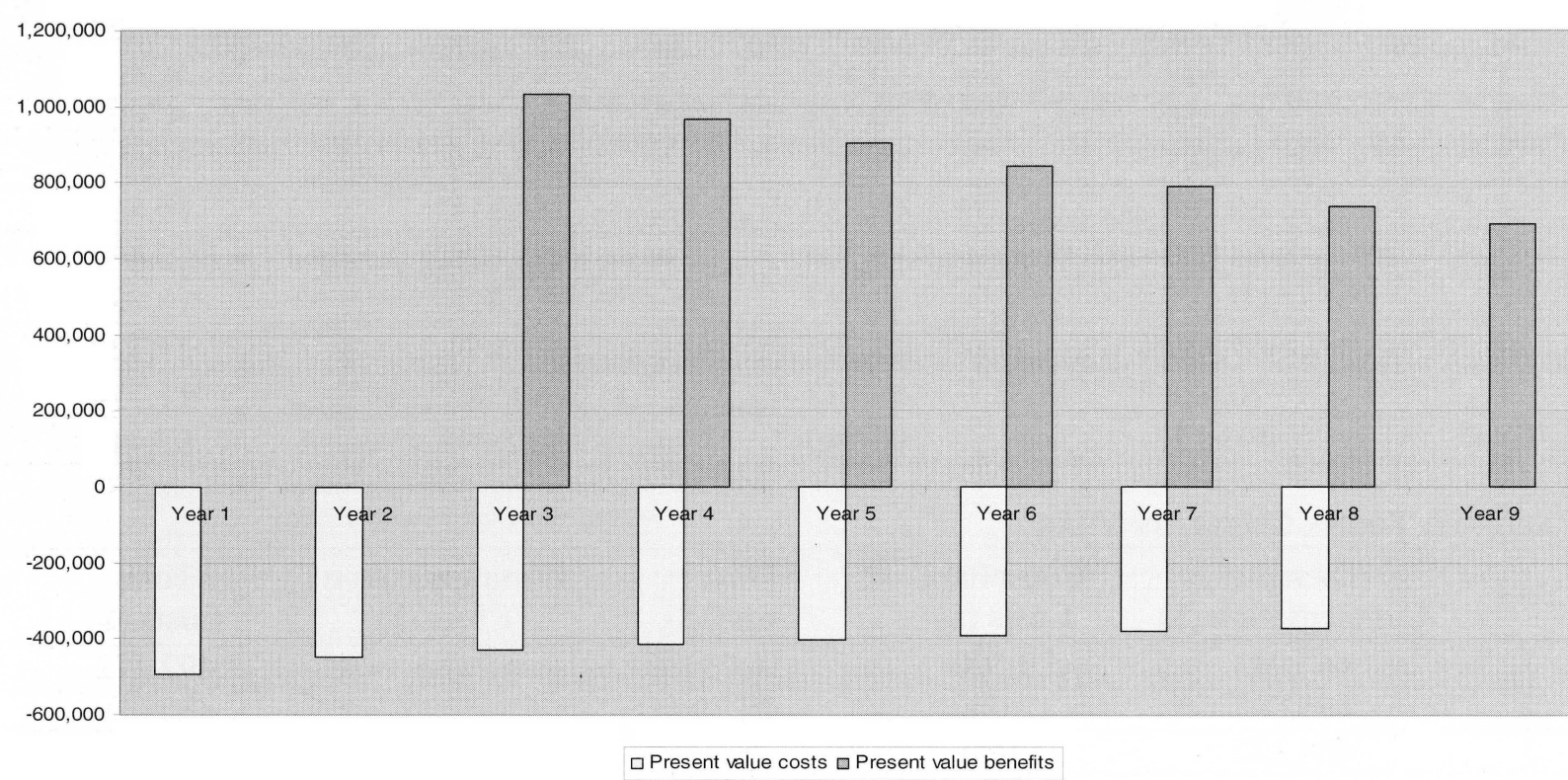

